\title{
How Much Redistribution Should There Be?
}

\author{
Daniel Markovits ${ }^{\dagger}$
}

\section{THE EGALITARIAN IDEAL}

Egalitarianism ties people's fortunes together. It takes the good and bad things in people's lives-their blessings and their afflictions-and shares them out, or redistributes them, among their fellows. Where egalitarianism operates, each person's fortunes and misfortunes cease to be just her own and become, to the extent egalitarianism recommends, a part of communal fortunes and misfortunes, shared in by all those who come under egalitarianism's purview. Egalitarian political theories are not the only ones to tie people's fortunes together; feudal theories, for example, do so as well. But egalitarianism differs from these and other political theories in the manner of its tying. Egalitarianism insists that all people's lives are equally important and, accordingly, that no person's fortune may be subordinated to anyone else's. ${ }^{1}$

Egalitarian intuitions call for redistribution that takes from the betteroff-the rich, the healthy, and the fulfilled - and gives to the worse-offthe poor, the sick, and the desolate. But these intuitions stand in need of elaboration, and an egalitarian theory answers this need by presenting an articulate account of nonsubordination among persons. ${ }^{2}$

† Associate Professor of Law, Yale Law School. Thank you to Bruce Ackerman, Anne Alstott, Joseph Altonji, Sarah Bilston, G.A. Cohen, Jules Coleman, Ronald Dworkin, Owen Fiss, Michael Graetz, Robert Green, Robert Hockett, Al Klevorick, Richard Markovits, Derek Parfit, Benjamin Polak, Mathias Risse, Jed Rubenfeld, Alec Walen, Bernard Williams, Patrick Wolff, and the participants in the first annual May Meeting of Young Law Professors for commenting on earlier versions of this Essay. Finally, thank you to Craig Estes for providing outstanding research assistance. All mistakes that remain are, of course, entirely my own.

1. The simplest forms of utilitarianism, which tie people's fortunes together by sacrificing individual fortunes whenever this maximizes total or average fortunes, also treat people equally by insisting that no person's fortune counts for more than any other person's. But the utilitarian account of equal treatment falls well short of egalitarian nonsubordination because it never compares individual fortunes against one another. Utilitarianism (on this account) is concemed exclusively with totals or averages; it takes no distributive view. As John Rawls has said, utilitarianism ignores the "distinction between persons," which is precisely the idea from which egalitarianism begins. JOHN RAWLS, A THEORY OF JUSTICE 27 (1971).

2. Egalitarianism, understood in the limited sense I am giving the term, is not a complete theory of equality. Egalitarianism, perhaps better called distributional egalitarianism, falls short of 
A fully developed conception of nonsubordination must address many practical or applied problems, including many problems that are familiar in the law, and egalitarian political theory has indeed been brought to bear on such problems in legal scholarship. Thus lawyers have, for example, considered egalitarianism's implications for the choice of the tax base, ${ }^{3}$ the legal treatment of disabilities, ${ }^{4}$ health-care policy, ${ }^{5}$ and even the role that cost-benefit analysis should play in administrative practice. ${ }^{6}$ But before these and other more specific issues can be approached with any measure of confidence or clarity, an egalitarian theory must address two more general, theoretical questions, and efforts to answer these questions must proceed in a more broadly philosophical vein.

The first question was made famous by Amartya Sen in the title of his 1979 Tanner Lecture Equality of What $?^{7}$ This question asks, in G.A. Cohen's words, "What aspect(s) of a person's condition should count in a fundamental way for egalitarians ... ?"8 It suggests that egalitarians search, as Cohen put it, for an equalisandum, a thing whose equal distribution

being a complete theory of equality because it restricts its attention in (at least) two ways. First, distributional egalitarianism considers only those areas of justice in which it is permissible to redistribute systematically and regularly. This distinguishes distributional egalitarianism from theories of political equality, particularly from the theory of equal political liberty. Second, distributional egalitarianism depends on earlier ideas about what makes people's lives go well, without which it is impossible to assess whose fortunes are good or bad and therefore who is at risk of being subordinated. These earlier ideas will themselves generally be the subject of controversy, as the several competing ethical ideals each seek to promote their own distinctive conceptions of the successful life. The effort to resolve this conflict neutrally, without discriminating against any ethical view-the effort to develop a theory of toleration-comprises another distinct element of a complete account of equality. Furthermore, conflicts may arise between distributional egalitarianism and these other parts of equality or between distributional egalitarianism and non-egalitarian values, such as efficiency. Elizabeth Anderson has made the former sort of conflict the theme of a recent article in which she criticizes the egalitarian tradition I shall develop here-the tradition she calls "equality of fortune"-for systematically encroaching on other elements of equality. Elizabeth S. Anderson, What Is the Point of Equality?, 109 ETHICS 287, 289 (1999). My aim in this Essay is limited to clarifying certain ideas within this tradition, so I shall not directly address Anderson's arguments. I hope, however, that some of the things I say, especially near the end of my argument, will generate useful suggestions for defusing Anderson's attack.

3. E.g., Edward J. McCaffery, The Uneasy Case for Wealth Transfer Taxation, 104 YALE L.J. 283 (1994); Eric Rakowski, Transferring Wealth Liberally, 51 TAX L. REV. 419 (1996).

4. E.g., Carlos A. Ball, Autonomy, Justice, and Disability, 47 UCLA L. REv. 599 (2000); Pamela S. Karlan \& George Rutherglen, Disabilities, Discrimination, and Reasonable Accommodation, 46 DUKE L.J. 1 (1996); Mark S. Stein, Ronald Dworkin on Redistribution to the Disabled, 51 SYRACUSE L. REV. 987 (2001).

5. E.g., RONALD DWORKIN, SOVEREIGN VIRTUE 307-19 (2000).

6. E.g., Mathew D. Adler \& Eric A. Posner, Rethinking Cost-Benefit Analysis, 109 Y ALE L.J. 165 (1999).

7. Amartya Sen, Equality of What?, in EQUAL FREEDOM: SELECTED TANNER LECTURES ON HuMAN VALUES 307 (Stephen Darwall ed., 1995).

8. G.A. Cohen, On the Currency of Egalitarian Justice, 99 ETHICs 906, 906 (1989). Cohen's emphasis establishes a contrast between fundamental aspects of a person's condition and other aspects that matter only "as a cause of or evidence of or proxy for what [egalitarians] regard as fundamental." Id. 
secures nonsubordination. ${ }^{9}$ Here it is critical that egalitarianism calls for the nonsubordination of persons, and the equalisandum must be chosen bearing this in mind. The proposal, for example, that everyone should be given an equally long name fails as a conception of egalitarianism because the length of someone's name does not capture what is important about her person, so that equality among name lengths is entirely consistent with subordination among persons. ${ }^{10}$

An egalitarian theory must also answer a second question, the question posed in my title, namely "How Much Redistribution Should There Be?"11 To do this, an egalitarian theory must develop a conception of nonsubordination that explains how the equalisandum, whatever it is, must be distributed in order for no person's fortune to be subordinated to any other's. Put slightly differently, an egalitarian theory must develop a view of what counts as an equal distribution of the equalisandum. Because the equal distribution will almost certainly not be the distribution produced in the ordinary course of economic and social activity, this means that an egalitarian theory must develop an account of redistribution.

This second question (the question concerning how much redistribution there should be) has been less intensively investigated than the first question (concerning the proper equalisandum). However, the second question is not any less central to egalitarianism (or any less important generally) than the first, and, as my title indicates, it is the question I explore here. ${ }^{12}$ I shall develop a view that is implicitly accepted by most

\section{Id. at 908 .}

10. Furthermore, other more plausible proposed equalisanda are said to suffer structurally analogous failures to underwrite an adequate conception of egalitarianism. For example, John Rawls and Ronald Dworkin have rejected the proposal that welfare captures the core concerns of equality because theories that focus on welfare cater to offensive or unusually expensive preferences in a manner that subordinates other people to those who hold such preferences. On this view, welfare is an inadequate equalisandum because although it is related to what is important about persons, the relationship is not straightforward, and welfare is certainly not all of what is important about persons. Thus, Rawls and Dworkin suggest, the focus on welfare becomes inconsistent with nonsubordination of persons when one person's welfare depends on attacking others (as in the case of offensive tastes) or when one person's welfare requires others to give up too much (as in the case of expensive tastes). RAWLS, supra note 1, at 30-31; Ronald Dworkin, What Is Equality? Part 1: Equality of Welfare, 10 PHIL. \& PUB. AFF. 185, 228-40 (1981) (this article appears in substantially unaltered form in DWORKIN, supra note 5, at 11-64).

11. A fully developed egalitarian view must also answer a third question--namely, over what unit must the equalisandum be equally distributed? This question takes two forms. First, it asks whether egalitarian nonsubordination should be applied-whether the equalisandum should be equally distributed-to individuals or to collectives (for example to families, geographic areas, or subcultures). Second, the question asks whether nonsubordination should be applied over the entire lifespan of the individuals or collectives in question, or over some shorter period.

12. I shall have little to say expressly in answer to the question "Equality of what?" although I must, at least implicitly, take some view of the correct equalisandum, if only to provide examples of egalitarian redistribution to think about. I suspect that the examples I choose will fit most naturally with Cohen's view that the proper equalisandum is access to advantage, but I admit right off that I make no effort to develop a general or theoretical account of access to advantage or indeed of advantage simpliciter. See Cohen, supra note 8, at 907 . I will, however, comment on the 
egalitarians, namely that nonsubordination requires redistribution to follow moral responsibility, specifically by eliminating luck's differential effects on persons' fortunes while leaving persons fully to bear the consequences of their (morally responsible) choices. I shall consider certain central features of this responsibility-tracking egalitarianism more carefully and completely than others have done, and this will lead me to conclude that the view's dual ambitions are unattainable, so that much of the most prominent philosophical discussion of egalitarianism involves a fundamental mistake. Finally, I shall introduce a new account of egalitarianism based on a new conception of nonsubordination that avoids some of the errors of the responsibility-tracking view.

\section{RESPONSIBILITY-TRACKING EGALITARIANISM}

The relative lack of attention received by the question "How much redistribution should there be?" is, perhaps, a product of the patterns of disagreement and agreement within the community of philosophers writing in the modern egalitarian tradition. Philosophers within this tradition disagree deeply about what equalisandum should count in a fundamental way for egalitarians. ${ }^{13}$ But they appear to display a remarkable consensus around the responsibility-tracking account of when an equalisandum is distributed equally, that is, so as to secure the nonsubordination of persons. I shall aim, ultimately, to break this consensus; but I begin by elaborating the view that sustains it.

The responsibility-tracking view begins from the observation that choice and luck jointly determine a person's fortunes. ${ }^{14}$ Her fortunes

question "Equality of what?" in order to point out that certain well-known disputes about the proper equalisandum are, in fact, more interestingly understood as disputes about the question "How much redistribution should there be?" See infra text accompanying notes 58 -68 (discussing expensive tastes).

13. See, e.g., RAWLS, supra note 1, at 90-95; AMARTYA SEN, INEQUALITY REEXAMINED (1992); Richard J. Arneson, Debate: Equality of Opportunity for Welfare Defended and Recanted, 7 J. POL. PHIL. 488 (1999); Richard J. Arneson, Equality and Equal Opportunity for Welfare, 56 PHIL. STUD. 77, 79 (1989); Cohen, supra note 8; Ronald Dworkin, Sovereign Virtue Revisited, 113 ETHICS 106 (2002) [hereinafter Dworkin, Sovereign Virtue Revisited]; Dworkin, supra note 10; Ronald Dworkin, What Is Equality? Part 2: Equality of Resources, 10 PHIL. \& PUB. AFF. 283 (1981) [hereinafter Dworkin, Equality of Resources] (this article appears in substantially unaltered form in DWORKIN, supra note 5, at 65-119); John Rawls, Social Unity and Primary Goods, in UTILITARIANISM AND BEYOND 159 (Amartya Sen \& Bernard Williams eds., 1982); Sen, supra note 7; Amartya Sen, Well-Being and Freedom, 82 J. PHIL. 185 (1985).

14. Luck, in this context, is what Dworkin has called brute luck-luck involving risks that could not have been anticipated or could not have been isolated and declined. Brute luck stands in contrast to option luck-luck involving risks that could have been isolated and declined, and perhaps even risks that have been isolated and accepted, as in the case of deliberate and calculated gambles. A person is not responsible for her brute luck because it is utterly out of her control, but she is responsible for her option luck, which she can control. Indeed, option luck is really a peculiar kind of choice, namely the choice to bear a risk. For more on this distinction, see Dworkin, Equality of Resources, supra note 13, at 293. 
improve or decline as she chooses well or badly and as her luck is good or bad. The crucial distinction between these two influences is that whereas a person is responsible for her choices, she is not responsible for her luck. ${ }^{15}$ (It makes sense in this context to say, for example, that whether or not a person has a happy marriage is significantly a matter of her choice of husband, whereas whether or not she had a happy childhood was significantly a matter of her luck in her parents.) Put in another way, one may understand people as being at once agents, who act upon the world in ways for which they are responsible, and patients, on whom the world acts in ways they cannot control. ${ }^{16}$ And, once people are understood in this way, it becomes natural to say that egalitarianism should treat them differently in their roles as agents and as patients. On the one hand, the distribution of advantage should be sensitive to differences in people's choices-there should be no redistribution to counter the differential effects of choice. On the other hand, the distribution of advantage should be insensitive to differences in people's luck-redistribution should eliminate the differential effects of luck. Taken together, these principles entail that egalitarianism should track responsibility-that is, they entail the responsibility-tracking view of how much redistribution there should be.

The responsibility-tracking view of redistribution is in this way intuitively attractive. Moreover, it is both an old position and one that has attracted widespread support in the contemporary philosophical literature on egalitarianism, often from people who cannot agree on other matters, including the proper equalisandum. ${ }^{17}$ John Stuart Mill, for example,

15. This idea obviously needs elaboration. A person is responsible for her choices only if she has reasonable alternatives to choose among (or if she is responsible for not having reasonable alternatives). Someone who is told, "Your money or your life," and chooses her life is not ordinarily responsible for this choice, as evidenced by the fact that she retains her claims to her money. I shall not offer any systematic account of these ideas, preferring instead to rely on hopefully shared intuitions about responsibility and to continue to note difficulties in the margin.

16. Of course, it will not always be easy to separate the effects of choice and luck in a particular case, something the example I have chosen also illustrates. People who suffer the bad luck of having certain kinds of parents may be raised in a way that leaves them unable to identify character traits that make for a good spouse or unable to marry people who have these traits, so that their earlier bad luck may infect their later "choice." But while this difficulty may matter later in the argument, when it comes time to allocate the various elements of people's fortunes to choice and luck respectively, we do not need to be able to distinguish choice and luck cleanly at this early stage. It is enough for now that when we consider the distinction we know what we are talking about.

17. Rawls is conspicuously absent from the list of philosophers presented to illustrate this claim in the main text. Rawls has, to be sure, suggested that egalitarianism should attack specifically those inequalities that are "arbitrary from a moral perspective," i.e., that it should "treat[] everyone equally as a moral person" and ensure that people's "share in the benefits and burdens of social cooperation" is not weighted "according to their social fortune or their luck in the natural lottery." RAWLS, supra note 1, at 74-75. But Rawls's theory nevertheless makes no express accommodation for responsibility's role in distributive justice: The principle of distributive justice Rawls officially espouses-the difference principle--departs from the responsibility-tracking view by allowing inequalities even though they reflect involuntary disadvantage as long as they redound to the benefit of the worst-off; and the primary goods by 
believed that "[t]he proportioning of remuneration to work done is really just only in so far as the more or less of the work is a matter of choice: when it depends on natural difference of strength or capacity, this principle of remuneration is in itself an injustice." ${ }^{\text {18 }}$ More recently, Ronald Dworkin has suggested that egalitarianism should track the distinction between people's persons and their circumstances, ${ }^{19}$ that it should be ambitionsensitive but may not be endowment-sensitive. ${ }^{20}$ Similarly, Cohen has argued that egalitarianism's "purpose" is specifically "to eliminate involuntary disadvantage," which he stipulates to mean "disadvantage for which the sufferer cannot be held responsible" because it does not

which Rawls would measure equality are more to some people's tastes than to others and will leave people differentially able to satisfy their ambitions, even where these ambitions are themselves involuntarily held. And indeed, Rawls has been taken to task for these features of his theory, most notably by Cohen and Arneson. See, e.g., G.A. Cohen, The Pareto Argument for Inequality, 12 SOC. PHIL. \& POL'Y 160 (1995); Richard Aneson, Primary Goods Reconsidered, 24 NOÛS 429 (1990). My own view is that responsibility does enter into Rawls's account of distributive justice in a number of complex ways, although not necessarily on the precise terms that responsibility-tracking egalitarianism recommends. As I am directing my attention to responsibility-tracking egalitarianism rather than to Rawls's work, I shall say no more about these matters here. An excellent general discussion appears in Samuel Scheffler, What Is Egalitarianism?, 31 PHIL. \& PUB. AFF. 5, 8-31 (2003).

18. John Stuart Mill, Principles of Political ECONOMy $211-12$ (W.J. Ashley ed., Longmans, Green \& Co. 1923) (1848) (emphasis added).

19. Dworkin, Equality of Resources, supra note 13.

20. Id. at 311. Dworkin puts the point even more directly elsewhere, saying, "In principle ... individuals should be relieved of consequential responsibility for those unfortunate features of their situation that are brute bad luck, but not for those that should be seen as flowing from their own choices." DWORKIN, supra note 5, at 287.

Although my principal interest in these pages is in equality directly rather than in Dworkin's theory of equality, the interpretation of Dworkin's views on this subject is itself a complicated matter. On the one hand, Dworkin's distinction between someone's person and her circumstances sounds very much like the distinction I have drawn between choice and luck, and this suggests that Dworkin adopts a version of the responsibility-tracking view. Cohen, for one, thinks Dworkin's distinction between someone's person and her circumstances is an effort to capture the distinction between choice and luck and to create an egalitarian view that tracks responsibility. Cohen calls this the "underlying motivation" of Dworkin's view and claims that insofar as Dworkin's view fails to live up to this motivation, it is mistaken. Cohen, supra note 8 , at 922 . On the other hand, and in spite of these features of his view, Dworkin has expressly said in the context of discussing particular cases of bad luck (including ill health and unemployment) that the effect of the redistribution he proposes "is not to eliminate the consequences of brute bad luck ... but only to mitigate it." DWORKIN, supra note 5, at 341; see also Dworkin, Sovereign Virtue Revisited, supra note 13, at 120 (accepting that even after the redistribution he proposes, the talented would have more income than the untalented). These remarks suggest that Dworkin rejects responsibility-tracking egalitarianism.

Any adequate interpretation of Dworkin's views on the subject of eliminating involuntary disadvantage must therefore explain the relationship between the basic principles that underlie Dworkin's general account of egalitarianism - the account he calls equality of resources-and his several proposals for addressing specific forms of involuntary disadvantage. In particular, the interpretation must address whether the limits on specific cases of redistribution that Dworkin supports reflect idiosyncratic, and perhaps even practical, concerns raised against the backdrop of a basic acceptance of responsibility-tracking egalitarianism or instead indicate a general and principled rejection of this view in favor of some alternative. Although I make no sustained effort to resolve these interpretive questions here, I will on occasion comment on them in the margin. See infra notes 76-77. 
"appropriately reflect" his choices. ${ }^{21}$ And John Roemer (commenting on this tradition of thought) has proposed that "society should indemnify people against poor outcomes that are the consequences of causes that are beyond their control, but not against outcomes that are the consequences of causes that are within their control, and therefore for which they are personally responsible."22 Accordingly, Roemer concludes, "all those who exercised a comparable degree of responsibility are equal, regardless of their circumstances. ${ }^{23}$ In spite of their differences concerning the choice of equalisandum, these egalitarians (and others as well ${ }^{24}$ ) converge on the responsibility-tracking view of how much redistribution there should be.

Furthermore, the widespread adoption of the responsibility-tracking ideal by egalitarians of all stripes is more than merely fortuitous. Responsibility-tracking egalitarianism is connected to an intuitively powerful conception of the ideal I began by claiming lies at the heart of egalitarianism - the ideal of the nonsubordination of persons. On this account, nonsubordination requires that people are treated differently in their capacities as agents and as patients. Specifically, if people are to be treated equally as agents, then their choices must distinguish them, but if people are to be treated equally as patients, then their luck may not distinguish them. One might say, in this vein, that responsibility-tracking egalitarianism requires that people are allowed to be agents separately but made to be patients together.

This is certainly a plausible position. Thus, when people are approached as agents, it seems that nonsubordination requires leaving each person equally to bear the consequences of her own choices, so that there may be no redistribution when people are separated by only their choices. When people are separated by only their choices, taking from a person who has chosen well in order to compensate another person for the bad consequences of her bad choices involves subordinating the first person to the second. It involves requiring the first person to bear a burden for which

21. Cohen, supra note 8 , at 916 .

22. John E. Roemer, A Pragmatic Theory of Responsibility for the Egalitarian Planner, 22 PHIL. \& PUB. AFF. 146, 147 (1993) (emphasis omitted).

23. Id. at 149 (emphasis omitted).

24. Richard Arneson, for example, has characterized this tradition as asserting that "the aim of justice as equality is to eliminate so far as is possible the impact on people's lives of bad luck that falls on them through no fault or choice of their own." Richard Ameson, Luck Egalitarianism and Prioritarianism, 110 ETHICS 339, 339 (2000). And Kasper Lippert-Rasmussen observes that "[a]s construed by the majority of its current supporters, egalitarianism accommodates choice and responsibility," Kasper Lippert-Rasmussen, Egalitarianism, Option Luck, and Responsibility, 111 ETHICS 548, 548 (2001) [hereinafter Lippert-Rasmussen, Option Luck]. Elsewhere, LippertRasmussen proposes, as an articulation of this responsibility-tracking ambition, that "[i]t is in itself bad with regard to equality if, and only if, people's comparative positions reflect something other than their comparative exercises of responsibility." Kasper Lippert-Rasmussen, Debate: Arneson on Equality of Opportunity for Welfare, 7 J. POL. PHIL. 478, 479 (1999). The examples could, of course, be further multiplied. 
he is not responsible - something the second person, who is after all the source of this burden, is not required to do. Alternatively, one might say that in such a case, the first person's choices have been appropriated in the interests of the second person, or that they have been used as a means to further the interests of the second person. The first person-viewed as an agent-has been quite literally subordinated to the second person in that his agency has been conscripted in the service of the second person's interests. For example, if one person has chosen to save and another has chosen to consume, then redistributing from the saver to the consumer in effect forces the saver to save on the consumer's behalf. ${ }^{25}$

But when people are approached as patients, it seems that nonsubordination requires luck to be treated in the opposite way, so that the consequences of luck are redistributed to make all people bear an equal portion. No one is more responsible for brute luck than anyone else, and so leaving one person to suffer worse luck while another enjoys better luck subordinates the first to the second. Allowing luck to lie where it falls in this way leaves the first person to bear a disproportionate share of a burden for which he and the second person are equally not responsible. In this case, the first person's interests have been sacrificed in order better to promote the second person's interests, even though the difference between the luck they enjoy is morally arbitrary. The first person has been subordinated to the second as a patient.

I shall investigate the responsibility-tracking account of how much redistribution there should be in the light of these ideas about nonsubordination. My aim is to shake up the consensus that has developed around the responsibility-tracking account by presenting an egalitarian investigation of the question "How much redistribution should there be?" that mimics the sustained attention to basic principle displayed by recent philosophical efforts to answer the question "Equality of what?"26 The

25. Although the consumer reaps the immediate benefit of this inequality, she may on further reflection object to it on the ground that it insults her. As Arthur Ripstein points out in a related context, this kind of redistribution-redistribution to undo a person's bad choices-treats this person "as a mere natural thing rather than as an agent." Arthur Ripstein, Equality, Luck, and Responsibility, 23 PHIL. \& PUB. AfF. 3, 13 (1994).

26. I hope in this way to begin to provide an analysis of how the equalisandum must be distributed in order to satisfy the demands of distributional egalitarianism that displays some of the rigor that familiar analyses of democratic voting and liberal neutrality have provided in connection with efforts to articulate the other elements of a complete account of equality mentioned supra note 2, namely the theories of political equality and toleration. Just as theories of democracy and neutrality articulate the demands equality imposes on the distributions of political power and sectarian privilege, so the theory of distributional equality secks to articulate the 
argument will involve focusing carefully-more carefully than responsibility-tracking egalitarianism has generally done so far-on the economic and, indeed, the actuarial features of egalitarian redistribution, certain of which may be given a philosophical interpretation. I shall use this method to ask whether the dual ambition of responsibility-tracking egalitarianism - the ambition to leave untouched disadvantage that stems from choice while eliminating disadvantage that stems from luck, to keep people absolutely separate as agents while binding them absolutely together as patients - can be achieved. I conclude that this ambition cannot be achieved, that eliminating all disadvantage that stems from luck requires treating people's choices unequally and, conversely, that equally respecting all people's choices requires leaving some involuntary disadvantage (some bad luck) in place.

Egalitarians must therefore choose between promoting the nonsubordination of persons as agents and the nonsubordination of persons as patients, and I shall conclude my argument by commenting on this choice. The thrust of these comments will be to argue for securing the nonsubordination of persons as agents even at the cost of sacrificing the nonsubordination of persons as patients. I shall argue, in particular, that this new conception of egalitarianism can defuse two extremist intuitions concerning nonsubordination that have heretofore plagued egalitarian political thought, although in very different ways: the libertarian idea that any interference with one person's actual choices in the service of another person constitutes subordination, and the collectivist idea that every failure to eliminate unchosen disadvantage constitutes subordination. Each of these ideas resonates with certain egalitarian intuitions but remains unsatisfying as a whole, not least because of the intuitive appeal of the other, opposed idea. ${ }^{27}$ Responsibility-tracking egalitarianism tries to satisfy both ideas together, but I shall argue it breaks under the strain of this effort.

demands equality imposes on the distribution of the equalisandum identified by answers to the question "Equality of what?"

27. One might say that egalitarianism's account of nonsubordination is subject to two constraints, which derive from the fact that persons are finite and yet also independent sources of moral claims. First, egalitarianism must respond to the finiteness of persons-it must recognize that things can happen to persons that lie beyond their control and responsibility, things for which egalitarian compensation is required. Second, egalitarianism must respond to the independence of persons - it must recognize that one person may not simply be used to serve another, even in order to undo a hardship or burden that the other does not deserve. Responsibility-tracking egalitarianism attempts perfectly to satisfy both these ends at once. But each end pushes against the other, and so the effort to satisfy both renders the responsibility-tracking view subject to criticism from each. Libertarians say that egalitarianism uses some-the luckier, more talented, and richer-to serve others-the less lucky, less talented, and poorer. And collectivists say that egalitarianism's sop to the independence of the more fortunate causes it to betray the less fortunate. I shall attempt a formal, theoretical development of these ideas-that is, to explain precisely why responsibility-tracking egalitarianism's dual ambition cannot be fulfilled and to provide an account of equality, in the shadow of this impossibility, that lowers the level of its ambition and can therefore answer critics from both sides. 
Responsibility-tracking egalitarianism's failure reveals the shortcomings of each idea and therefore points the way toward a new and improved account of egalitarian nonsubordination.

\section{EQUAL AGENCY}

Consider more carefully the idea that the nonsubordination of people as agents is secured by holding people responsible for their choices in the sense of refusing to redistribute to ameliorate disadvantages that are the result of the sufferer's choices. Clearly, responsibility-tracking egalitarianism cannot make good on this idea simply by requiring people to bear the consequences of whatever choices they actually make. Luck operates to give people differentially attractive choices - that is, choices among differentially attractive alternatives-before they have chosen anything at all (for example, luck gives some people better health or richer parents or more desirable genetic endowments than others, and these people choose among commensurately more attractive alternatives). Certainly no one is responsible for facing the unusually attractive choices this thought contemplates; after all, no one can possibly have chosen to be in this position. The egalitarian idea of tracking responsibility aims at a state in which people's fortunes are separated by only their choices, but leaving people to bear the consequences of their actual choices will never achieve this state. Instead, it will lock in place inequalities in the choices people face (and perhaps even suggest that these inequalities are legitimate). For this reason, leaving people to bear the consequences of their actual choices subordinates people whose worse luck has made their choices less attractive to people whose better luck has made their choices more attractive. It subordinates them as patients for the straightforward reason that it leaves their worse luck uncompensated, and it also subordinates them as agents, by holding them equally responsible for their choices even though their worse luck has left them facing less attractive possibilities for agency.

Instead of leaving people to bear the consequences of their actual choices, egalitarianism must secure for people equal opportunities for choice-opportunities to choose among equally attractive alternativesbefore requiring them all to bear the consequences of their own choices. The trouble is that it is impossible simply to remove the effects of brute luck on people's opportunities for agency. Genetic endowments and parental attention, for example, cannot be directly redistributed because this is technologically impossible, because values like liberty and privacy would prohibit transferring these goods, because it is impossible to say what average levels of these goods are, or for some combination of these and other reasons. Accordingly, egalitarianism must seek instead to compensate for bad luck's effects on agency by redistributing independent physical 
resources, such as money. ${ }^{28}$ Egalitarian theory must therefore determine how much compensation-how much redistribution-removing luck's effects on agency requires.

I adopt Dworkin's response to this problem and claim that the right way to think about these matters is to imagine that people who know the distribution of luck but do not know what their own peculiar luck will be are offered insurance against suffering bad luck. ${ }^{29}$ The insurance policies offer compensation to people who turn out to be disadvantaged by bad luck, and the compensation is paid for not out of premiums collected before luck's intervention but rather out of taxes levied after luck's intervention on people who turn out to be advantaged by good luck. Finally, and critically, all people are offered the same choice of policies, and all people face the same tax rates for any given level of coverage. ${ }^{30}$

Because the participants in this hypothetical insurance market are offered identical policies at identical rates, they face equally attractive choices and have equal opportunities for agency. Thus, Dworkin's idea of imaginary insurance provides a powerful and intuitively compelling account of the nonsubordination of people as agents. According to this account, no person is subordinated to any other as an agent when all people have an equal capacity to make their lives match their ambitions, where this includes (not at all paradoxically) having an equal capacity to protect against bad luck that prevents them from making their lives match their ambitions. ${ }^{31}$ Furthermore, any redistribution beyond that generated by the insurance scheme subordinates the lucky to the unlucky as agents. It imposes premiums on the lucky to pay for insurance they would not have bought in the equal insurance market; and it provides the unlucky with the benefits of insurance they would not have paid for. Indeed, the only way in which this greater redistribution could have come out of the insurance scheme is if the lucky had faced higher rates than the unlucky. But this would have left them less capable of making their lives match their ambitions than those who faced lower rates. It would have subordinated them as agents.

Now my aim is not to develop a complete egalitarian theory based on the model of insurance but rather to use this idea to investigate the intuition

28. For similar points, see Dworkin, Equality of Resources, supra note 13, at 300-01.

29. See id. at 292-304. Others have proposed similar methods for determining how much redistribution nonsubordination requires. The most famous, of course, is Rawls's Original Position. See RAWLS, supra note 1, at 118-92.

30. The insurer, we may assume, is risk-neutral, incurs no transactions costs, and sets the tax rates-the insurance rates - in order to break even rather than to turn a profit. This treatment of the insurer is both important and somewhat controversial. I discuss it further infra note 76.

31. As Dworkin says, insurance secures for everyone "an equal opportunity of mitigating the disadvantage [caused by bad luck] by insuring against it." Dworkin, Equality of Resources, supra note 13 , at 331 . 
that egalitarianism should track responsibility, and consequently I make no effort to explain the model in exhaustive detail. Nevertheless, it will be useful for what follows to address some elements of the model more carefully, to identify others I do not address, and to point to certain conceptual problems the model must overcome.

First, the question arises whether the insurance scheme should set tax rates and compensation rates separately for each person, depending on the amount of insurance that person would actually have bought, or whether all people should be taxed and compensated based on the policy a representative person would buy. Dworkin argues in favor of the second alternative, and I agree. Disadvantages and advantages affect people's ambitions and therefore also affect how much insurance against brute luck people will buy. An indeterminacy therefore arises-the luck a person has had affects how much insurance against bad luck a person will buy. Because of this, one cannot tell, simply by asking him, how much insurance against his disadvantage an unlucky person would have bought. (This is particularly worrisome when a person's bad luck takes the form of being untalented because lack of talent may make people lose certain ambitions and therefore underreport how much insurance they would have bought.) This indeterminacy is so great that it justifies providing, for everyone, the policy that a representative person would buy. ${ }^{32}$ This approach also fits well with the hypothetical nature of insurance-based egalitarianism more generally. The idea is not to defend redistribution by claiming that actual people have in fact bought insurance policies, but rather to defend redistribution because equal agency requires it, as the hypothetical insurance model reveals. ${ }^{33}$

Second, it is necessary to identify the disadvantages or classes of disadvantages against which insurance should be offered, although it is clear right from the start that insurance can be offered against involuntary

32. For a similar argument, see id. at 297-98 \& n.6, 316-17.

33. This brief discussion glosses over many significant difficulties, which a complete egalitarian theory would have to overcome. Although I do not address any of these difficulties here, one in particular is worth pointing out. The observation that the level of advantage people enjoy affects the ambitions they have-their sense of what makes a life go well and indeed what counts as advantage quite generally - reopens the worry that egalitarianism is neccssarily constructed on top of controversial ideas about what good and bad fortune involves and gives this worry a point of attachment within egalitarian theory itself. It is not difficult to imagine, for example, that a dissatisfied genius and a satisfied simpleton each think the other suffers a disadvantage that engages egalitarian concern, and egalitarianism (at least insofar as it depends on egalitarian insurance) cannot proceed until it resolves the dispute between them. Resolving this dispute raises difficult questions concerning other elements of equality. See supra note 2. Certainly Mill's famous response, which was to side with the genius more or less by fiat, signally fails to address the problem. See MILL, supra note 18, at 10-11. Moreover, this problem-of measuring people's holdings of the equalisandum in a neutral (and hence egalitarian) way-is not merely an artifact of the particular egalitarian scheme that I am imagining but plagues other approaches to egalitarianism as well. The problem of neutrality also plagues Rawls's approach to egalitarianism and, in particular, his reliance on primary goods. See supra note 17. 
disadvantages only: against bad luck, but not against bad choices. Insurance against bad choices, as I have said, involves the subordination as agents of those who choose well to those who choose badly. ${ }^{34}$ (Moreover, the problem of moral hazard renders insurance against bad choices literally a nonsense, because the price of insuring against bad choices will incorporate the costs of these choices, so that the insurance, rather than protecting against these costs, will simply shift them to an earlier time.) Dworkin, who hopes to construct a complete theory of distributional equality, expends considerable effort and ingenuity in identifying the disadvantages against which insurance should be offered. His theme, which he presents in many variations, is that insurance should be offered against lacking resources but not against having low welfare. I shall not try to improve on Dworkin's efforts generally, although I will make piecemeal comments on some of the arguments and conclusions Dworkin proposes in this regard.

Finally it is necessary briefly to consider the question whether or not the basic distinction between choice and luck can be held. Skepticism about this distinction comes in two forms, one moderate and one radical. Moderate skepticism about the distinction between choice and luck does not doubt that the distinction makes sense conceptually but instead doubts our ability ever to apply the distinction to any particular case of disadvantage in order to say whether choice or luck lies behind it. If moderate skepticism is

34. Disadvantage due to differential option luck has been thought by some to present a difficult problem in this connection because option luck has been seen to fall uncomfortably between choice and chance. Thus, Lippert-Rasmussen worries about a case in which two people reasonably choose identical gambles, and one wins and one loses. Lippert-Rasmussen observes that the two people are not responsible for the difference in advantage that arises between them in such a case, and he suggests that this difference should therefore be a subject for egalitarian concern and redistribution. See Lippert-Rasmussen, Option Luck, supra note 24, at 572-75. My own view of this kind of a case is that the redistribution Lippert-Rasmussen contemplates, which enforces (as Lippert-Rasmussen himself observes) a risk-pooling among the gamblers, must be rejected because it is inconsistent with the egalitarian aim of the nonsubordination of persons as agents. Voluntary risk-pooling is one thing, but enforced risk-pooling discriminates against those with a taste for risk by reducing the range of choices available to them, and, in this way, it subordinates them to their more risk-averse counterparts.

These observations do not, I admit, defuse Lippert-Rasmussen's concern that the people in the case he imagines enjoy differential advantage without being responsible for the difference and therefore, to use the language I introduced in the main text, that a refusal to redistribute subordinates the unlucky gambler to the lucky as a patient. Insofar as this is so, the example foreshadows my central claim that responsibility-tracking egalitarianism is unattainable because the nonsubordination of persons as agents is inconsistent with the nonsubordination of persons as patients and my subsidiary suggestion that, in cases of conflict, the nonsubordination of persons as patients should be sacrificed and the nonsubordination of persons as agents preferred. The principal burden of my argument is to show that this pattern of reasoning applies not just to marginal cases for egalitarian concem, involving differential option luck, but also to core cases involving differential brute luck.

Finally, nothing I have said addresses Peter Vallentyne's interesting analysis of the problem of option luck and his suggestion, in effect, that zero risk-pooling may not be the appropriate background against which to measure egalitarian concerns. See Peter Vallentyne, Brute Luck. Option Luck, and Equality of Initial Opportunities, 112 ETHICS 529, 549-56 (2002). 
true, then it will be impossible to give an adequate account of the disadvantages against which egalitarian insurance is offered or to say, for any particular disadvantage, whether or not it is covered by such insurance. I shall not say anything about this problem, not least because I take it to be more a problem for psychology than for philosophy, one which calls for a factual inquiry into the origin and character of particular choices rather than a conceptual inquiry into the nature of choice quite generally. ${ }^{35}$

Radical skepticism, by contrast, raises just such general questions, doubting that the distinction between choice and luck makes sense conceptually. As Cohen points out with characteristic clarity and honesty, egalitarian views that aim to eliminate involuntary disadvantage or to track responsibility may leave us "up to our necks in the free will problem."36 This form of skepticism raises the familiar worry that determinism might be true and might make a nonsense of the very idea of choice or agency, so that when we distinguish between choice and luck, between agents and patients, we in fact do not know what we are talking about. This, of course, is a problem for philosophy-if it is not, then what is? Nevertheless, I shall have little to say about this issue either, except to suggest that one possible interpretation of the hypothetical insurance market is as a way of avoiding the free will problem altogether, at least in the context of egalitarian redistribution. The idea of insurance may ground an account of moral responsibility that is adequate to the needs of distributional egalitarianism, independent of the free will problem, and capable of surviving the truth of determinism and the correctness of the incompatibalist response to that truth. Perhaps, for example, it is enough for distributional egalitarianism (under some principle still in need of development) to set people's responsibility not according to such actual choices as they have freely made, but rather according to the insurance they would have bought in the hypothetical insurance market Dworkin's egalitarian view imagines. ${ }^{37}$

35. This last claim may somewhat overstate its point. John Roemer's work on equality of opportunity illustrates that it can be a philosophical problem to develop a framework for distinguishing between choice and luck in particular cases. See JOHN ROEMER, EQUALITY OF OPPORTUNITY (1998). Furthermore, Mathias Risse observes that the philosophical problems involved in such an effort are intimately connected to some of the central traditional philosophical problems of freedom of the will, including the complex of problems concerning determinism and compatibalism. See Mathias Risse, What Equality of Opportunity Could Not Be, 112 ETHICS 720 (2002).

36. Cohen, supra note 8 , at 934 .

37. Indeed, Dworkin himself sometimes appears to employ ideas about responsibility that differ from the choice-based ideas underlying the egalitarianism I consider in the main text. In particular, Dworkin claims that people have a duty to form ideals and ambitions with a sense of their cost to others. See DWORKIN, supra note 5, at 285-99; Dworkin, Equality of Resources, supra note 13, at 288-89. He sometimes uses this idea to hold people responsible even for ideals and ambitions they have not chosen. For more on this idea, see infra text accompanying note 65.

For an alternative effort to internalize ideas about equality to the notion of responsibility, see Ripstein, supra note 25. 
Instead of addressing these and other questions in an effort to develop and defend the insurance model of nonsubordination, I focus on a different problem. I begin from the insurance model's account of egalitarian nonsubordination of people as agents and ask how this is related to the egalitarian ambition I described earlier-the ambition of tracking responsibility. I ask, in effect, where securing the nonsubordination of people as agents as the insurance model proposes leaves people as patients. Does it eliminate involuntary disadvantage, thereby securing the nonsubordination of people as patients also? I conclude that it does not. In two cases at least people will not buy enough insurance against suffering particular disadvantages to eliminate the effects of luck on the distribution of advantage and indeed will necessarily reject such high levels of insurance as fundamentally unacceptable to them. In both these cases, people who face equally attractive choices will choose not to compensate completely for the differential effects of luck on their lives. I shall argue, in other words, that securing the nonsubordination of people as agents by insisting that all people should bear the consequences of their own (equally attractive) choices is inconsistent with securing the nonsubordination of people as patients by eliminating involuntary disadvantage. The egalitarian ambition of tracking responsibility is unattainable.

\section{EGALITARIAN INSURANCE}

I have claimed that securing the nonsubordination of people as agents requires accepting some involuntary disadvantage and the subordination of people as patients that this entails. Two examples - involving disadvantages due to involuntary lack of talent and involuntary expensive tastes-serve to develop and illustrate this point. In each case, people offered equal opportunities to insure against involuntarily suffering the disadvantage at issue will not buy enough insurance to eliminate the involuntary disadvantage. People whose nonsubordination as agents is secured by the hypothetical insurance market will choose to allow luck to subordinate them to one another as patients. Furthermore, although developing the examples depends on working through certain elements of egalitarian insurance in some detail, it will be possible, once the examples are in place, to recast them as illustrating a larger, more intuitive idea.

\section{A. Talents}

For present purposes, I shall call one person less talented than another if she can trade her labor for fewer resources, which is to say, in a market economy, that she can command a lower wage. For example, someone who can find employment only as an unskilled laborer is less talented than a 
surgeon. Therefore, insofar as possessing resources is an advantage, being untalented is a disadvantage and being involuntarily untalented is an involuntary disadvantage. Accordingly, an egalitarian theory based on the imaginary insurance scheme I have described will compensate people who are involuntarily untalented. I shall consider how much compensation it will provide. The interesting question is whether it will provide-whether people will buy-enough insurance to eliminate the effects of luck on the distribution of advantage by causing some people involuntarily to be less talented than others.

To answer this question, consider how the insurance scheme would work in this case, once again using Dworkin's account of the scheme as a staging point for my own arguments. To begin with, Dworkin says, the insurance scheme cannot work by allowing people to insure against not having particular abilities: The connection between particular abilities and ambitions is too close to allow us to say what policies of this sort people would buy ${ }^{38}$ Instead, says Dworkin, we must suppose that people know what abilities they have, but not what wage these abilities command. Furthermore, we suppose that people know the distribution of possible wages and that their place in this distribution-the wage that their talents will turn out to command-will be chosen at random. ${ }^{39}$ Insurance is then offered against involuntarily "failing to have an opportunity to earn whatever level of [wage] income, within the projected structure, the policy holder names." ${ }^{, 40}$ If the risk eventuates, the insurance company pays the policyholder the difference between his coverage level and the highest wage he has the opportunity to earn. Premiums depend on the policy and not the policyholder and are paid out of the future earnings of people for whom the risk does not eventuate-that is, of people who are talented enough to earn higher wages than the level they insured against. ${ }^{41}$

38. Dworkin, Equality of Resources, supra note 13, at 316.

39. In fact, people may know the distribution of possible income distributions, but this complication is unnecessary here. Furthermore, it is relevant at all only insofar as people care not just about their own incomes, but also about the relationship between their incomes and other people's.

40. Dworkin, Equality of Resources, supra note 13, at 317. Note that the involuntary disadvantage the insurance protects the policyholder against is not simply earning a low wage because he has chosen not to eam up to his potential but rather being unable to earn a high wage. Accordingly, the insurance scheme bases premiums on potential rather than actual wages. Borrowing a phrase from tax lawyers, one may say that it allocates to each person an impufed wage equal to the difference between what she might earn and what she does cam. This feature of the policies entails that the problem of moral hazard-the problem that the insurance a person holds may affect his behavior and hence also the chance that the insured-against risk eventuatesdoes not arise in connection with the insurance scheme I am imagining. For comment on these matters, see infra note 74 .

41. Dworkin, Equality of Resources, supra note 13, at 317. Dworkin does not say clearly whether, in his model, premiums are paid only when the risk does not eventuate or in all cases. I an inclined to choose the former interpretation and accordingly to structure insurance policies so that they guarantee net-of-premium income levels. It seems to me that this is the natural way to 
In order to eliminate the disadvantage involved in being involuntarily untalented, people would have to buy insurance against being any less talented than average, against being able to command any less than the mean wage. But in fact, people offered the egalitarian insurance I have imagined would not insure up to the average talent level, so that even though insurance will diminish luck's effects on the distribution of advantage, it will not eliminate these effects.

To see why not, begin by noting that insurance against falling below the mean talent level is the very most insurance anyone could ever afford to buy. ${ }^{42}$ This is an actuarial identity. No insurer could ever afford to offer policies that insure (net-of-premiums) up to anything above the mean wage, simply because insurance at a higher level than the mean will, on average, pay out more than it takes in. ${ }^{43}$ If everyone buys policies against not having (net-of-premiums) higher than the mean talent level, then the insurance company will be able to pay out on all the policies, and leave everyone better off than average, only by creating rather than just redistributing wealth, which it cannot do. ${ }^{44}$

Furthermore, even policies that insure only up to (rather than above) the mean wage must be supported by a draconian premium structure. In order to break even on such policies, an insurer must collect, as premiums, all wages the policyholder has the opportunity to earn above the mean wage level in case she has the good luck to be more talented than average. To see that this is so, imagine that the insurance company allows the holder of such

describe the policy from the insured person's point of view. She wants to guarantee herself a certain net income, and she is indifferent (all else equal) between having less net income because she cannot earn more and having less net income because she must pay an insurance premium. Saying that insurance coverage up to a certain level of income guarantees that income level netof-premiums is a kind of truth in advertising. It will also make some of the arguments to come clearer. For further discussion of this choice, see infra note 50.

42. For simplicity's sake, I shall again assume throughout that the insurance scheme generates no transactions costs. Dropping this unrealistic assumption complicates the exposition but only strengthens the force of my conclusions.

43. Dworkin's several discussions of the insurance scheme appear not to notice this actuarial point. In his original presentation, he finds it necessary to argue, for example, that people will choose not to insure against having anything less than the highest talent level, Dworkin, Equality of Resources, supra note 13, at 319-20, and he suggests that people might actually buy insurance against not earning above the sixtieth percentile of the income distribution, which, in a normal distribution at least, lies above the mean, $i d$. at 323. Moreover, Dworkin's later presentations of the insurance scheme again treat insurance up to or even above the average wage level as possible, for example, when he says that "no hypothetical prudent person would buy insurance that would guarantee him even the average wage of those in employment, let alone wages equal to those that the highest earners gather." DWORKIN, supra note 5, at 340.

Dworkin's emphasis on the several reasons for which policies securing these above-average wages would not be bought obscures the more fundamental fact that they could not possibly be offered.

44. If wealth could be created out of nothing in this way, then the problems egalitarianism addresses would not arise, because the conditions of scarcity that create these problems would not exist. (I am grateful to Jed Rubenfeld and Robert Hockett for pressing me to emphasize this point.) 
a policy to keep some wages above the mean level. Then (as a result of holding the policy) her net-of-premium earnings will sometimes be at the mean and sometimes above the mean. But this is impossible, as we have already seen. Once again, it could happen only if insurance created wealth rather than just redistributing it.

So insurance up to the mean wage level is affordable only if the policyholder always works up to her maximum earning potential and always pays any earnings above the mean to the insurance company as a premium. But someone in this condition is, as Dworkin observes, ${ }^{45}$ a slave to her talents. In order to maintain the mean wage level while also paying the premiums on her insurance policy (which depend on her earnings potential rather than her actual earnings), she must always work flat out and only at that job which, given her talents, pays most. She would be forced to work at this job, and this job only, even if she hated the work involved, had ambitions that she could fulfill only in another job, or just preferred the other job. ${ }^{46}$ And, as Dworkin points out, no reasonable person would accept

45. Dworkin, Equality of Resources, supra note 13, at 320. Although I borrow the idea of talent slavery from Dworkin, its role in my argument is importantly different from its role in his. Dworkin introduces the idea of talent slavery "in order to explain why people would not buy insurance that guaranteed the very highest wage levels," see id. at 319-23, and turns to other, more pragmatic arguments (described infra note 76 ) when he suggests that people might not insure up to the mean. By contrast, I rule out above-mean insurance on actuarial grounds and turn to the argument concerning talent slavery to explain why people would not insure even up to the mean wage. This difference between our two approaches will turn out to be important: My approach emphasizes a connection between talent slavery and the elimination of involuntary disadvantage that Dworkin's obscures, and this connection will figure prominently in my overall assessment of responsibility-tracking egalitarianism.

46. The badness of talent slavery-the thing that makes people avoid insurance policies that create the risk of talent slavery-raises complications that require further treatment. Talent slavery may be understood in terms of well-being, so that the critical feature of talent slavery is that people who owe high insurance premiums must take jobs they do not like, i.e., jobs whose net-ofenjoyment return is low (even if their wage is high). But as Cohen points out, the right metric for measuring the advantage conferred on someone by her work is not simply her wage but rather her wage adjusted by the "labor burden" her work imposes on her. Cohen, supra note 17, at 172-75. Thus, when a talented person can earn a high wage only by doing work he finds overwhelmingly burdensome, the person does not enjoy net good luck. He is lucky in his talents, to be sure, but this good luck is outweighed by his bad luck in his tastes, for he suffers from having the expensive taste of finding burdensome those jobs that pay high wages (in a market economy, these are the jobs whose work product other people value). When the problem of talent slavery is characterized this way, the question the main text addresses becomes whether people will buy insurance against being any less talented than average when they can also buy insurance against having the expensive taste of finding high-paying jobs unusually burdensome. Dworkin's own view of egalitarianism avoids this aspect of the problem entirely, by insisting that expensive tastes (including, presumably, the taste of finding well-paid work burdensome) should not generally be insurable or trigger egalitarian redistribution. See Dworkin, Equality of Resources, supra note 13, at 301-03. On Dworkin's view, the complication contemplated in this footnote therefore does not arise.

Moreover, even if expensive tastes should be insurable and should trigger egalitarian redistribution, the conclusion argued for in the main text remains correct. For one thing, the next Section, which discusses insuring against expensive tastes, will make plain that even people offered such insurance will not insure up to the mean net-of-labor-burden wage level. But beyond this, and more fundamentally, the badness of talent slavery should be understood as involving not 
the risk of such slavery in exchange for insurance up to the mean wage level when insurance up to a lower wage level can be obtained without risking talent slavery. Buying insurance up to the mean wage level exchanges a large chance of a moderate gain (the difference, roughly, between a lower insured wage and the mean wage in case one is untalented) for a large chance of a great loss (being a slave to one's talents in case one is talented), which is a bad exchange on any accounting. ${ }^{47}$ Accordingly, all people will insure only up to a wage level that falls below the mean wage level. ${ }^{48}$

This suggests asking how close to the mean wage level an insurance policy can get without imposing the risk of talent slavery on the policyholder. That question has no general answer-its answer in particular cases depends on the distribution of wages and on the range of jobs that pay each wage. But it is possible to identify the two factors that will affect the answer in specific cases. To determine the highest talent-slavery-safe level of insurance, one must know first how near to their maximum earning potentials people of various talent levels can be forced to work without talent slavery's setting in. And, second, one must know, for insurance up to some wage level $W$ below the mean, what percentage of the difference between her actual earning potential and $W$ a person must pay as a premium, in case her actual earning potential lies above $W$. If the answer to the second question is high enough so that, in order to pay their premiums (without having a net-of-premium wage level below $W$ ) talented people must work nearer to their maximum earning potentials than the answer to the first question allows, then no person can insure up to $W$ without risking talent slavery.

merely an unwanted labor burden but a deprivation of freedom, so that a critical feature of talent slavery is that the need to pay insurance premiums determines the jobs a person can take. Thus, someone might wish to avoid owing premiums that force her to take high-paying jobs even though she does not find these jobs burdensome and might do them even if she did not owe the premiums. Such a person suffers no unusual labor burden and therefore cannot claim compensation based on having an expensive taste, but she will nevertheless wish to avoid suffering talent slavery. This way of characterizing the problem of talent slavery reveals that people will not insure up to the mean wage level no matter how much insurance against having expensive tastes, including tastes that create unusual labor burdens, they also possess.

47. Notice in particular that this argument does not depend on the idea that people are riskaverse. Even risk-neutral people will reject a deal that exchanges a large chance of a moderate gain for a large chance of a great loss.

48. Robert van der Veen has presented an alternative model of redistributive insurance in which he claims that people would insure up to much higher levels. See Robert van der Veen, Equality of Talent Resources: Procedures or Outcomes?, 113 ETHICS 55, 67-75 (2002). Van der Veen's model, however, fails to respond to the arguments presented in the main text. It treats work as a single undifferentiated commodity and bases the taxes that the talented pay on their actual rather than their maximal wages (and their actual rather than maximal hours worked). Van der Veen's proposal therefore abstracts from precisely those features of the world-involving the variety of work and effort-that drive the argument in the main text. 
Furthermore, as the talent distribution becomes more dispersed, and particularly as the median and the mode of the distribution fall further below the mean (as the talent distribution develops a tail at the high end), the maximum talent-slavery-safe level of insurance will for two reasons also fall further below the mean. First, under these circumstances, the cost of insuring up to some fixed level below the mean but above the median and mode-the premium structure associated with this level of insurancerises to approach the cost of insuring up to the mean wage level. ${ }^{49}$ Second, as talent distributions become more dispersed, the range of jobs that generate any given wage, and particularly the range of jobs that generate a high wage, decreases. And, accordingly, the extent to which the need to earn at a certain level in the distribution in order to support insurance premiums determines the job a person does increases (because the person will have fewer relatively high-earning jobs from which to choose). These two effects entail that as the talent distribution becomes more dispersed, and particularly as the median and the mode of the distribution fall further below the mean (as the distribution develops a tail at the high end), insuring even at levels below the mean will require people to pay a greater proportion of their maximum wage as premiums, premiums a smaller range of jobs will enable them to support. For both reasons, the maximum talentslavery-safe level of insurance will in such cases fall further below the mean. $^{50}$

49. When the wage distribution is dispersed, so that the median and mode lie far below the mean $(\mu)$, then for wage levels $W<\mu$ but greater than the median and mode wages, it will generally happen that a very low percentage of total wages is earned by people earning between $W$ and $\mu$. In such cases, an insurance company that wishes to cover the expected payouts of policies that insure up to $W$ must set premium schedules that are very much like those it would have to set in order to cover the costs of policies up to $\mu$. (Not much wage income separates the two policies.) And these premium schedules, we have seen, generate the risk of talent slavery. This is, of course, an intuitive rather than a formal proof, and the use I make of means and medians is meant to illustrate a general phenomenon rather than to cover all conceivable cases.

50. It is tempting to resist this conclusion by resisting as artificial the constraint, imposed in the main text, that when a person insures against being unable to command a wage above $W$ she also supposes that, should she turn out to be talented, she will insist on a net-of-premium wage of at least $W$. Perhaps the talented will happily work at a wage below the highest wage they can command even though doing so reduces their net-of-premium wage to below $W$ (the wage, remember, they sought to secure in case they were untalented). And if this is the case, then the threat of talent slavery will loom less large in the hypothetical insurance problem, and the solution to this problem will involve insurance that comes commensurately closer to securing the mean wage.

This response, however, involves several mistakes. First, insofar as it is motivated by the thought that a talented person may tum out not to mind low net-of-premium wages (or that the talented as a class may be particularly likely not to mind low wages) and therefore may not experience the need to pay premiums as limiting her choice of jobs, it fails to recognize that this is not a permissible form of thought from the perspective of the decision about how much insurance to buy. Someone who does not mind low wages enjoys a piece of good fortune that is distinctive in its own right and that, insofar as it is involuntary, itself becomes a subject of concern for egalitarian redistribution. (Such a person enjoys, as I shall say in the next Section, the good fortune of having a cheap taste.) A person choosing an insurance policy therefore cannot count on 
Finally, talent distributions in actual economies are often quite dispersed, and the median and the mode often lie quite far below the mean. This is true even in developed economies that support a large middle class. For example, the standard deviation of the wage distribution in the United States in 1999 was roughly $\$ 60,000$, and the median wage was roughly $\$ 23,000$ while the mean wage was roughly $\$ 38,000 .^{51}$ Assuming that this

the possibility that she may not mind paying premiums, because the benefits associated with this possibility will themselves be redistributed away from her. And for this reason, a person choosing an insurance policy must assume that failing to secure a given net wage because of the obligation to pay premiums is as undesirable as failing to secure the same wage because of lacking talent.

Second, the suggestion that a person may discount the risk of talent slavery out of a willingness to accept net-of-premium wage levels below the level she insured to protect against misconstrues the scope of the problem of talent slavery, especially as it arises with respect to wage (talent) distributions that have a long tail at the high end. Such distributions do not merely have the feature that the talented can command much, much higher wages than the mean. They also arise out of economic systems in which even the most talented can command such wages only in association with a highly limited set of highly specialized activities. Given the size of the premiums that the most talented in such distributions must pay in the service of redistributive insurance that secures the mean (or even the median) wage for all, the problem of talent slavery does not arise only because they seek to guarantee themselves a net-of-premium wage at the insured-against level. Instead, the problem of talent slavery arises with respect to the most talented because (as an actuarial matter) the most talented must guarantee themselves a net-of-premium wage that is at least zero; they must, in other words, earn a wage at least equal to the premiums they owe. And given (1) the small range of jobs at which the most talented can earn the maximum wage available to them, (2) the substantial difference between this wage and the highest wage that is consistent with a wide choice of jobs, and (3) the size of the premiums that the most talented would owe under an insurance scheme that guaranteed near the mean income, it could easily happen that the premiums a highly talented person owed under such a scheme were greater than the highest wage paid by any job such a person found attractive to do.

Both of these observations reinforce the conclusion reached in the main text, namely that the risk of talent slavery will induce people to insure against being untalented only up to a level that falls below (and, in dispersed distributions that have a long tail at the high end, substantially below) the mean talent level.

51. I have compiled these statistics using data from the Internal Revenue Service. See David Campbell \& Michael Parisi, Individual Income Tax Returns, 1999, STAT. INCOME BULL., Fall 2001, at 34, at http://www.irs.gov/pub/irs-soi/99indtr.pdf. I am reporting rough numbers only because the data do not support more precise calculations. This is particularly true of the standard deviation that I report, which, in fact, represents a lower bound on the wage distribution's true standard deviation. (The recorded data do not report individual persons' wages but only the number of persons whose wages fall within certain ranges. The standard deviation that I have calculated underestimates the true standard deviation because it does not include that component of the true standard deviation that arises out of wage variation within these ranges.)

Moreover, the distributions of wages in underdeveloped countries are even more dispersed and even more unequal than in the United States. Certainly, income inequality is greater overall in such countries: The Gini coefficient for the U.S. income distribution in 1997 was 40.8 , whereas the Gini coefficients for South Africa during 1993-1994 and Brazil in 1997 were 59.3 and 59.1, respectively. See WORLD BANK, WORLD DEVELOPMENT INDICATORS 70-72 (2001).

To illustrate the point even more graphically, imagine a distribution in which ten people can, by doing a wide variety of tasks, command a wage of 100 and one person can, by doing a highly specialized task, command a wage of 1,000,000. (Imagine further that this one could also command a wage of 100 by doing any of the wide variety of tasks open to the other ten.) If the wage of 100 translates into a sufficiently comfortable life, and the highly specialized task is attractive (or indeed bearable) only to sufficiently unusual tastes, it becomes easy to imagine that people facing this distribution of talents might purchase no insurance against being untalented. Any such insurance, any insurance that guaranteed a wage greater than 100 , would impose premiums on whomever turned out to be able to earn $1,000,000$ that would require her to work at 
wage distribution mimics the talent distribution, ${ }^{52}$ someone who insured up to only three-quarters of the mean talent level and turned out to be capable of earning $\$ 1$ million per year (less than the mean salary of partners in New York City's 15 most profitable law firms, ${ }^{53}$ and less than the median salary of people holding the rank of vice president or higher at New York City's investment banks ${ }^{54}$ ) would have to pay roughly $\$ 500,000$ as insurance premiums, and only $0.43 \%$ (fewer than 1 in every 200 ) of the jobs in the American economy would allow her to pay these premiums while maintaining the net-of-premium wage she had insured to protect. ${ }^{55}$ Even if

the one task at which she could earn this amount, and this might well involve a risk no one was prepared to take. (I owe this example to Anup Malani.)

52. Although my argument depends on the distribution of potential wages, I have employed the distribution of actual wages in this illustration. These two distributions are, of course, distinct, and if potential wages are less dispersed than actual wages, this will weaken my argument. I suspect, however, that the distribution of potential wages is if anything more dispersed than the distribution of actual wages. The diminishing marginal utility of money means that the poor are likely to value marginal wages more highly than the rich and are therefore more likely to earn up to their full potentials. I have also treated the dispersion in the distribution of wages as reflecting luck rather than choice. This may seem to adopt a controversial assumption, but although there is a lively scholarly debate about whether wage inequalities are caused principally by social determinants involving family background or by genetic determinants involving $I Q$, there seems to be little dispute that some combination of these two factors--both of which involve luck rather than choice-explains a substantial portion of wage inequality. On this point, see, for example, CHRISTOPHER JENCKS, WHO GETS AHEAD? 50-84 (1979); and Gary Solon, Intergenerational Mobility in the Labor Market, in 3 HANDBOOK OF LABOR ECONOMICS 1773 (O. Ashenfelter \& D. Card eds., 1999). Moreover, other involuntary factors besides family background and geneticsfor example, market factors that determine the demand for a person's particular talents-also affect wages. And the results presented in the main text are so robust as to withstand, qualitatively, some substantial decrease in the involuntary dispersion of the talent distribution.

53. See A Smaller Millionaires' Club, AM. LAW., July 2002, at 151.

54. For these data concerning the wages of vice presidents, directors, research directors, and managing directors of New York's investment banks, see Wall Streeters Get Richer, BUS. WK. ONLINE, Nov. 20, 2000, at http://www.businessweek.com/2000/00_47/b3708175.htm. Business Week also reported that 4000 such New York investment bankers earned at least $\$ 1$ million in 2000. See Emily Thomton \& Heather Timmons, The Street's Punishing Pay Siubs, BUS. WK. ONLINE, Nov. 20, 2000, at http://www.businessweek.com/common_frames/ca.htm?/2000/ $00 \_47 / \mathrm{b} 3708174 . \mathrm{htm}$.

55. This premium reflects the application of modestly progressive insurance rates to those whose talents enable them to earn more than threc-quarters of the mean wage - that is, it reflects a modest effort to eliminate involuntary differences in wages not just as between the "untalented," who receive payouts, and the "talented," who pay premiums, but also within the class of the talented. If one tried to eliminate involuntary differences in wages within the talented class, so that the only involuntary wage differences to survive egalitarian redistribution were those that arose, as between the untalented and talented, as a result of the initial decision to insure up to only threequarters of the mean wage, then a person who could earn $\$ 1$ million per year would have to pay roughly $\$ 950,000$ in premiums, and only $0.16 \%$ (fewer than 1 in 500 ) of the jobs in the American economy could support such premiums. Finally, even if one were indifferent to involuntary wage differences within the talented class and simply set a flat tax rate across all talented persons, those who could earn $\$ 1$ million per year would have to pay roughly $\$ 300,000$ in premiums, and only $1.91 \%$ (fewer than 1 in 50 ) of the jobs in the American economy could support such premiums. These numbers have been calculated on the basis of the data compiled in Campbell \& Parisi, supra note 51 .

Moreover, none of these calculations would change much if one abandoned the aim of ensuring net-of-premium wage levels at three-quarters of the mean and sought instead to ensure 
this person were capable of doing all the jobs in the $0.43 \%$ (which is far from clear), she would be significantly enslaved by her talents. A person who carried such insurance and was capable of finding work as a Wall Street lawyer or banker, say, could not afford to work at almost any middleclass job (she could not, for example, be a doctor or a university professor or an engineer). ${ }^{56}$ I suspect that people would not be willing to accept this risk and would instead insure only up to talent levels that fall even further below the mean. ${ }^{57}$

These are general remarks only, but together they make it quite clear that people would insure only up to talent levels that fall significantlymore than $25 \%$-below the mean. But in order to eliminate the disadvantage involved in being involuntarily untalented, people would have to insure right up to the mean talent level. Accordingly, the insurance scheme that secures equal choice does not eliminate the differential effects luck has on the distribution of advantage by causing some people to be involuntarily less talented than others.

\section{B. Tastes}

One person has more expensive tastes than another if she needs more resources to achieve the same level of welfare. For example, someone

net-of-premium wage levels greater than zero. For someone who has to pay half a million dollars in premiums, the roughly $\$ 30,000$ difference between the two cases becomes insignificant.

56. I have chosen these examples in part based on my casual observation that many, if not most, doctors, engineers, and professors would have succeeded as lawyers and bankers.

57. This train of thought suggests two other observations that are not necessary to my main argument but are sufficiently important to be worth making anyway as asides. First, egalitarian theories of the type I am considering make the extent of just redistribution of advantage a function of the original distribution of advantage. This is most striking in the case of redistribution in the face of differences in people's talents-differences in the wages they can command for their labor. Some economic systems make the wage a person can command much more sensitive to the tasks he can perform than others do because the kinds of work they involve and the mechanisms by which they value work make for a much greater dispersion in the productivity and value of people's labor. Advanced capitalism has this feature of generating vast differences in the wages different people can command, whereas subsistence agriculture, for example, does not. It might be thought, moreover, that this original distribution, rather than redistribution, should be the real focus of egalitarian concern.

Second, and relatedly, the wage someone's talents can command depends on the demand for the things he can produce (this is just the analogue of the familiar thought that the expensiveness of a person's tastes depends on the demand for the things he desires). Realizing this makes it possible to give an intuitive answer to the common anti-egalitarian argument that people deserve the fruits of their talents. The answer is that these fruits are not simply a function of their talents but also of many other things, and the bearers of talents certainly can't deserve to live in a world that makes their talents valuable. The strongest case for this argument presents itself when certain talents - for cxample, the talents of the private money-manager-are valuable only if there exist very rich people - only, that is, if the distribution of wealth is highly unequal. The value of such a talent cannot be an independent reason justifying the unequal distribution of wealth because it depends on the unequal distribution of wealth. Even if the anti-egalitarian premise about desert is granted, the anti-egalitarian conclusion does not follow. 
whose happiness depends on owning a large house with private grounds has more expensive tastes than someone who is contented to live in a rented apartment. ${ }^{58}$ Therefore, insofar as welfare is an advantage, having expensive tastes is a disadvantage and involuntarily having expensive tastes is an involuntary disadvantage. Accordingly, people who suffer involuntary expensive tastes trigger an egalitarian claim for compensation. I shall consider how much compensation an egalitarian theory based on the imaginary insurance scheme I have described will provide. The interesting question, once again, is whether people will buy enough insurance to eliminate the effects luck has on the distribution of advantage when it causes some people involuntarily to have more expensive tastes than others.

Before considering this question, however, I must address an earlier problem involving the application of the insurance model to disadvantages caused by involuntarily held expensive tastes. Dworkin thinks a proper understanding of egalitarianism reveals that this model should not be applied to involuntary tastes generally but only to tastes that (in addition to being involuntary) are also unwanted -to "craving[s]" or "obsession[s]" or "lust[s]" or other "drive[s]" whose bearer would rather be without." Understood in this way, egalitarianism plainly fails to eliminate luck's effects on the distribution of advantage because it offers no compensation for the bad luck of having involuntary, but nevertheless not unwanted, expensive tastes. This peculiar feature of Dworkin's view has been identified and criticized, by Cohen (among others), for failing to live up to the responsibility-tracking motivation that gives Dworkin's general approach its power. ${ }^{60}$ But this criticism is internal to the responsibilitytracking ideal; it proposes an amendment to Dworkin's expressed view in the service of this ideal and does not reach the question I am addressing here, namely whether the responsibility-tracking ideal is itself attainable or attractive. In order to bring this question into proper focus I must "correct" Dworkin's view, as it were, to bring its treatment of expensive tastes in line with the responsibility-tracking program. Only by considering a view that has been modified in this way can I lay any remaining failure to eliminate involuntary disadvantage caused by expensive tastes at the feet of responsibility-tracking egalitarianism itself and thereby develop my claim that the responsibility-tracking ideal is unattainable and should be rejected.

58. The idea of expensive tastes is intuitively straightforward, and I shall not develop a theory of expensive tastes here. Such a theory would explain how to make at least rough comparisons both of the amounts of resources different people consume and of the amounts of welfare this generates.

59. Dworkin, Equality of Resources, supra note 13, at 302. Dworkin says that tastes a person wishes she were rid of-cravings, obsessions, lusts, and so on-are more properly understood as handicaps than as expensive tastes and that egalitarianism should clearly aim to eliminate the disadvantages they cause under this heading. Id. at 301-03.

60. See Cohen, supra note 8 , at 922 . 
Dworkin proposes two arguments in support of excluding expensive tastes from egalitarian insurance, and any effort to bring such insurance into line with the responsibility-tracking ideal must answer both. First, he claims that except in the case of tastes people do not want, we cannot imagine people losing their tastes or ambitions without "imagining them to have a different conception of what they want from life than what in fact they do want." ${ }^{, 61}$ And without knowing what this different conception is, we cannot tell what insurance policy against expensive tastes people would buy. Dworkin thinks that insuring against having expensive tastes one wants to have does not make sense because in this case one has no basis-no tastes or ambitions-from which to explain the decision to insure or how much insurance to buy. This indeterminacy is analogous to an indeterminacy Dworkin discerned when he considered insurance against being untalented, namely that the connection between particular abilities and ambitions is too close to allow us to say what policies against not having particular abilities people would buy.

This argument against applying the insurance model to expensive tastes that are not unwanted fails because it misdescribes the bad luck against which people who have involuntary but not unwanted expensive tastes see themselves as insuring. When someone who has an expensive taste is asked to account for his attitude to it, it is open to him to say that while he does not wish to be rid of the taste, he does wish that it were not so expensive. ${ }^{62}$ He wishes, for example, that the resources needed for satisfying the taste were more plentiful than they are, that the technologies through which these resources are made to satisfy the taste were more efficient than they are, or that the demand for these resources and technologies were lower than it is. Such a person buys insurance not against having the taste, but rather against turning out to live in a world in which it is expensive, and to determine how much insurance to buy, he consults the tastes he has. ${ }^{63}$ Indeed, this solution to the indeterminacy that Dworkin says plagues insurance against having expensive tastes is analogous to the solution Dworkin himself proposed to the indeterminacy he discerned in the case of insurance against lacking specific talents. There, Dworkin solved the problem by proposing that insurance be offered not against lacking particular talents but rather against being unable to command a specified wage with whatever talents one has. Here, I solve the problem by proposing that insurance be offered not against

61. Dworkin, Equality of Resources, supra note 13, at 303.

62. Cohen, supra note 8, at 927.

63. A certain problem arises when this argument is applied to compensation for snob tastes. Snob tastes are tastes someone has for things because they are expensive, and so the willing bearers of snob tastes cannot mind living in a world in which their tastes are expensive and therefore cannot offer the account of their decision to insure that the main text proposes. The case of snob tastes presents problems for the insurance model of redistribution; but it is a pathological case, involving a paradox of self-reference, and the problems it presents are easily contained. 
having a particular taste but rather against being unable to satisfy whatever tastes one has for less than a specified sum. ${ }^{64}$

Dworkin's second reason for thinking that people should not be allowed to insure against involuntary expensive tastes they accept having is that he believes people are responsible for forming their tastes with an eye to what they will cost others. He believes, in other words, that the intuition that underwrites the egalitarian enterprise I am investigating - that people should not suffer involuntarily-does not apply to the case of expensive tastes people accept having, tastes for which they are to blame (even if the tastes are involuntary).

This is a fascinating (and possibly profound) suggestion, but it abandons egalitarianism based on the distinction between choice and luck in favor of an alternative egalitarian ideal, which Dworkin's argument leaves undefended. ${ }^{65}$ The idea of responsibility at the heart of the idealthat people are responsible for their expensive tastes because they have an obligation (independent of voluntariness) to form their tastes with an eye to what they will cost others-makes sense only on an understanding of responsibility that has already been moralized by the correctness of the rest of Dworkin's theory of equality (the theory he calls "Equality of Resources"). It assumes rather than supports the correctness of this theory,

64. Dworkin has responded to some of these criticisms of his views concerning tastes. I make no effort systematically to address Dworkin's responses here, but 1 do want briefly to explain why I find what he says unpersuasive.

Dworkin's response amounts, in the end, to two claims. First, he claims that viewing expensive tastes as a disadvantage is inconsistent with the understanding most people have of their tastes-namely, that these are not mere means to satisfaction but are instead justified on independent grounds. Tastes are, as Dworkin puts it, "soaked in judgment," DwORKIN, supra note 5 , at 290-91, and this entails, Dworkin believes, that to treat expensive tastes as compensable bad luck would be "to treat ourselves as dissociated from our personalities," id. at 290 . But this view remains open to precisely the point that I press in the main texi-namely, that a person may regret not her tastes but their price, and may (precisely because she views her tastes as justified) view their price as a disadvantage that warrants compensation.

Dworkin eventually admits (in responding to Cohen's version of this argument, Cohen, supra note 8 , at 927) that "this argument, if successful, would certainly undermine [the] claim that expensive tastes should not entitle anyone to extra resource[s]." DWORKIN, supra note 5, at 298. $\mathrm{He}$ asserts, however, that the argument is not successful, specifically because "[ $t$ ]he mix of personal ambitions, attitudes, and preferences that I find in my community, or the overall state of the world's resources"- the set of circumstances that fixes the expensiveness of my tastes-"is not in itself either fair or unfair to me; on the contrary, that mix is among the facts that fix what it is fair or unfair for me to do or to have." Id. Dworkin claims, in other words, that the price of a person's taste is not an ordinary, compensable misfortune for that person but rather part of the background conditions for his claims for compensation. I do not understand this claim. I also do not understand why, if this claim is correct, the analogous claim with respect to talents is mistaken-why the wage a person's talents command remains a source of a compensation claim rather than a background condition. This returns the argument to the difference in Dworkin's treatment of talents and tastes and reemphasizes that Dworkin must defend this difference.

65. As 1 suggested in note 37 , this ideal may be the beginning of a response to radical skepticism about the distinction between choice and luck. The ideal's most complete, thoroughgoing development possibly appears not in Dworkin's work but in Rawls's. This interpretation of Rawls appears in Scheffler, supra note 17, at 9-12, 24-31. 
including the correctness of the theory's handling of expensive tastes. ${ }^{66}$ Cohen, as I have said, suggests that Dworkin's alternative account of responsibility therefore involves a mistake, that whatever plausibility Dworkin's theory has comes from its approximating the idea that egalitarian redistribution should track responsibility understood in terms of the distinction between choice and luck. ${ }^{67}$ I prefer to reserve judgment on Dworkin's alternative egalitarianism, insisting only that egalitarianism based on the distinction between choice and luck remains worth investigating, both in general and in the form of the insurance model, now reconstructed to include insurance against involuntarily having tastes that turn out to be expensive. ${ }^{68}$

With these preliminaries cleared out of the way, I return to my primary concern, namely whether people offered egalitarian insurance modified to include insurance against involuntary expensive tastes would buy insurance up to the levels required to eliminate the differential effects that luck, in the form of involuntary expensive tastes, has on the distribution of advantage. I believe they would not. To see why not, consider how an imaginary egalitarian insurance market against involuntary expensive tastes might work. Imagine that people know what their tastes are but not how expensive their tastes will be. Instead, they know the distribution of the expensiveness of tastes and also that the place their tastes occupy in this distribution will be chosen at random. People are offered insurance policies against involuntarily having tastes whose expensiveness rises above whatever level they choose. If they purchase insurance, they will receive compensation for having expensive tastes insofar as the expensiveness of their tastes rises

66. The idea that people should not be allowed to insure against involuntary expensive tastes because they have an obligation to form their tastes with an eye to what they will cost others also introduces a tension into Dworkin's theory because it means that the theory, in yet another way, treats tastes and talents inconsistently. Dworkin does not believe that people should be prevented from insuring against involuntary lack of talent or that they have an obligation (independent of voluntariness) to develop their talents with an eye to how they will benefit others. But the underlying theme of the last several paragraphs has been that tastes and talents are analogous, that the expensiveness of tastes and the value of talents are determined in the same way, namely by other people's desires and capabilities coordinated through the market. This further analogy between tastes and talents once again makes it difficult to see how Dworkin can justify treating the two cases so differently.

67. See Cohen, supra note 8 , at 922 .

68. Dworkin offers a third objection to including insurance against involuntary expensive tastes in the model, namely that to do so is to abandon resources in favor of welfare as the equalisandum. I will not join the argument about the proper equalisandum, and so I leave this objection essentially unanswered. Still, two points are worth making even if only in passing. First, I am not sure that the third objection adds anything to the second: The root of Dworkin's preference for resources over welfare as equalisandum seems to be his belief that people are responsible for forming their tastes-their means to welfare-with an eye to what they will cost others in resources. And second, the problem of insuring against expensive tastes suggests that the resource/welfare distinction may in fact be impossible to sustain. The argument in the main text reveals that people who insure against having expensive tastes view themselves as lacking a resource-namely, the resource of a world in which their tastes are cheap. 
above the level they have insured against (policies guarantee the capacity to satisfy tastes as if their expensiveness did not rise above the level the policies name). This compensation is paid for through premiums collected from people who have purchased insurance but turn out to have cheap tastes.

In order to eliminate all disadvantage involved in having involuntary expensive tastes, people would have to buy insurance against having tastes that are any more expensive than average. Someone who held such a policy would be guaranteed that no matter how expensive her (involuntary) tastes turned out to be, she would receive payments that left her no less able to satisfy them than if they were only as expensive as average. At the same time, the premiums needed to cover these payouts would be so high that no matter how cheap her tastes turned out to be, she would be no more able to satisfy them than if they were as expensive as average. Any difference between the expensiveness of the policyholder's tastes and average expensiveness would be eliminated, either through payouts or through premiums (just as would occur if people held insurance against being any less talented than average). Accordingly, such a person's insurance policy would make her effectively indifferent to the expensiveness of her involuntarily held tastes. ${ }^{69}$

Insurance against having involuntary tastes that are any more expensive than average, and the redistribution that such insurance generates, will therefore leave each person to bear effectively none of the costs of his involuntary expensive tastes. Furthermore, someone who holds an insurance policy that makes him indifferent to the expensiveness of his involuntary tastes has effectively no incentive to employ his will in controlling his tastes for expensiveness. Instead, he will treat his tastes in the way in which most people treat, for example, their spoken accents--that is, as being per se involuntary because they are not worth the attention of the will. But someone who disengages his will from the question of the expensiveness of his tastes will develop, on average, much more expensive tastes than he otherwise would, because he will cease to engage in the (costly) behaviors through which people ordinarily control the

69. I say "effectively" indifferent rather than "absolutely" indifferent because even a person who holds insurance against having tastes that are any more expensive than average will not be compensated for the full increase in the expensiveness of her tastes insofar as this increase also increases the average expensiveness of tastes that serves as a baseline against which her claim for compensation is measured. (Even a person who holds insurance against having tastes that are any more expensive than average will bear that portion of an increase in the expensiveness of her tastes that appears as an increase in average expensiveness.) But, critically, in a society of any size, the effect of an increase in the expensiveness of one person's tastes on the average expensiveness of tastes is much smaller than the size of the increase (in a society of $n$ persons, the effect on the average is $1 / n$ of the size of the increase). In a society of any size, the proportion of an increase in the expensiveness of a person's tastes that she will bear is consequently vanishingly small (in a society of one million persons, it is one ten-thousandth of one percent). 
expensiveness of their tastes, for example not trying things they know they will be unable to afford. ${ }^{70}$ Finally, such a person's tastes will still be involuntary in the sense required for their being covered under his insurance policy. He will not have chosen them, nor will he have chosen specifically to fail to avoid them; instead, he will just have left them to chance (which is precisely what makes them involuntary).

For these reasons, the redistribution contemplated by insurance against having involuntary tastes that are any more expensive than average will prove cripplingly burdensome to any society that underwrites it. The joint effect of the increases in the expensiveness of each person's tastes will be to raise dramatically the average expensiveness of people's tastes (without creating any new resources with which to satisfy these tastes), leaving every person in the society much worse off. ${ }^{71}$ This effect could be cured while maintaining insurance against having tastes that are any more expensive than average only by adding to such insurance policies the condition that people who hold insurance at this level must subject the development of their tastes to an independent program of control for expensiveness. Butespecially given that insurance protecting only against having tastes that are much more expensive than average would not generate any comparable explosion in the expensiveness of tastes and would not need to be coupled with external control of the expensiveness of policyholders' tastes ${ }^{72}$-no one would buy the fully compensatory policies. It is one thing for people to disengage their own wills from controlling the expensiveness of their tastes; it is quite another for people to agree to subject this development to control by someone else. Insurance against having tastes that are any more expensive than average therefore necessarily involves an attack on people's persons that they would not accept.

70. This is, of course, a version of a result that is completely familiar to economists. Someone who holds insurance against involuntarily having tastes that are any more expensive than average will internalize effectively none of the social costs of his expensive tastes, which will appear as externalities. And externalities are undercontrolled by the unregulated behavior of those who cause but do not bear them.

71. It is important to notice, in this connection, that this general result does not change each individual person's incentives with respect to her own tastes. Even as the joint effect of the several individual responses to the insurance policies is to raise the average expensiveness of tastes in a way that leaves everyone worse off, each individual remains under no incentive to reduce the expensiveness of her own tastes. Although each person bears substantial costs as a consequence of the expensiveness of everyone else's tastes, each person continues to bear effectively no costs as a result of the expensiveness of her own tastes. In this way, insurance against having tastes that are any more expensive than average generates a prisoners' dilemma, together with the unpalatable consequences that this involves.

72. Such policies pay compensation only to people who involuntarily have very expensive tastes, and even then the compensation the policies pay reflects the difference only between the policyholder's actual tastes and the already expensive tastes the policy names, rather than the much larger difference between the policyholder's actual tastes and the mean tastes. This familiar device, which amounts to little more than building a high deductible into the insurance policies, means that people who hold such policies will retain an incentive to moderate the expensiveness of their tastes. 
Dworkin was wrong to think that the insurance scheme developed to secure equal choice should not underwrite redistribution for people who have involuntary (but not unwanted) expensive tastes. But at the same time, people will not buy enough insurance to support eliminating the differential effects involuntary expensive tastes have on the distribution of advantage. How much insurance against involuntary expensive tastes people will buy remains an open question. It is even possible that they will choose to insure only against expensive tastes that are unwanted as well as involuntary, in which case Dworkin will have reached the right conclusion for the wrong reasons. ${ }^{73}$ But whatever the right view of the question turns out to be, and I do not investigate the matter further here, it is clear from what has been said already that the insurance scheme fails to eliminate the differential effects luck has on the distribution of advantage by causing some people involuntarily to have more expensive tastes than others. ${ }^{74}$

73. People will certainly be more willing to submit to an external program controlling the development of unwanted tastes than to a program controlling the development of expensive tastes more generally.

74. A difference between the structures of the arguments involving talents and tastes deserves a final comment. The earlier argument concerning talents structured insurance against being untalented so as to solve the problem of moral hazard-this was reflected in the fact that premiums depended on potential rather than actual wages. The later argument concerning tastes structured insurance against having expensive tastes in a way that did not solve this problem-this was reflected in the fact that those who had insured against having expensive tastes no longer concerned themselves with the costs of their tastes. This difference is reflected in the precise argument raised against insuring at levels that would eliminate involuntary disadvantage in each case. Thus, in the context of talents, where the moral hazard problem was presumed solvable, each person carried (directly) the entire cost of insuring up to the mean, and this was a cost no rational person would be willing to bear. In the case of tastes, by contrast, where the moral hazard problem was presumed unsolvable, each person directly carried effectively none of the cost of insuring up to the mean. But this led to individual behavior that was collectively unacceptable and to a necessary regulatory response that, once again, no rational person would be willing to bear.

The point of observing this difference is to see that the two arguments are more powerful jointly than severally. When they are put together, they reveal that each argument's conclusionthat rational persons would not be willing to accept the intrusive consequences of carrying insurance up to the mean-is not merely an artifact of the peculiar model of redistributive insurance that the argument adopts. Regardless of how insurance is structured, insuring against eliminating all involuntary disadvantage - insurance that guarantees means-can function only by intrusively interfering in people's fortunes in ways that no rational person would accept. The effect of the specification of the insurance model is limited to determining the precise mechanism for the intrusion: whether it functions through a demand to pay premiums (as in the model applied to talents) or through central control over personal choice (as in the model applied to tastes).

Indeed, wholly analogous results could be achieved in each case by reversing the modeling assumptions in the main text. As regards talents, if the moral hazard problem were unsolvable, so that premiums depend on actual wages, then insurance against earning anything less than the mean wage would necessarily be accompanied by some form of highly intrusive control over which jobs people performed. And as regards tastes, if the moral hazard problem were solvable, so that premiums were based on the cheapest tastes a person could possibly acquire rather than on her actual tastes, insurance against having tastes any more expensive than average would necessarily involve a highly demanding premium structure under which people who were able to develop very cheap tastes could pay the premiums only by pursuing these tastes, regardless of any reasons they had for pursuing other tastes. 
People who are offered egalitarian insurance that secures equal choice will not buy enough to eliminate the effects luck has on the distribution of advantage by causing some people to suffer involuntary lacks of talent or involuntary expensive tastes. Instead, they will insure only at lower levels, which leave some involuntary disadvantage (some disadvantage for which the sufferer is not responsible) in place. ${ }^{75}$ This remaining involuntary disadvantage could be eliminated only by redistributing more extensively than the insurance model allows. ${ }^{76}$

75. It is tempting to make a final effort to deny this conclusion, by arguing that while people are not responsible for being untalented or having expensive tastes, they are responsible for the fact that they experience these things as disadvantages because that fact is a consequence of their choice not to buy more insurance. As Dworkin himself suggests, the availability of insurance can turn brute luck into option luck, which is properly understood as a species of choice. Dworkin, Equality of Resources, supra note 13, at 293. However, the circumstances in which people turn down the additional insurance reveal that this argument should not be applied to the case at hand. In this case, people lurn down the additional insurance because the risks of talcnt slavery and tastc indoctrination make it unreasonable for them to do otherwise. Turning down additional insurance does not involve choosing to accept a risk that could have been isolated and declined. Instead, it involves preferring the lesser of two risks that cannot both be avoided-preferring the risk of inadequate redistribution over the risk of talent slavery or taste indoctrination. Someone facing these risks chooses not to insure up to the mean only in the sense in which someone facing a bandit chooses to give up her money in order to save her life. In neither case is the person responsible for the disadvantage she suffers because this disadvantage does not, as Cohen might put it, "appropriately reflect" her choices. Cohen, supra note 8, at 916 (emphasis added).

76. Others have also noted that egalitarian insurance fails to eliminate the effects of luck on the distribution of advantage. Indeed, I observed earlier, see supra note 20, that Dworkin's own presentation of the insurance model concedes that it would leave the talented with more income than the untalented. Moreover, Michael Otsuka has recently emphasized this feature of the insurance model in the course of assessing and criticizing Dworkin's overall views. See Michael Otsuka, Luck, Insurance, and Equality, 113 ETHICS 40, 49-50 (2002).

For Dworkin, and also for Otsuka, the reasons for insuring only at levels that leave some involuntary disadvantage in place are principally prudential and pragmatic. Dworkin observes that some forms of brute luck-for example, severe physical or mental handicaps-are so bad that no society could eliminate them without "crippling itself." DWORKIN, supra note 5, at 341. Accordingly, Dworkin concludes, insuring to eliminate all involuntary disadvantage would be "irrational." Dworkin, Sovereign Virtue Revisited, supra note 13, at 124. Otsuka similarly worries about "extreme, leveling-down deprivation and transfer" and calls egalitarian insurance that requires such extreme redistribution "unreasonable." Otsuka, supra, at 45. Such practical considerations-including the incentive effects of redistributive insurance and even the "market" realities of moral hazard and "the nced for profit to the insurance company and its investors," Dworkin, Sovereign Virtue Revisited, supra note 13, at 108-are essential to Dworkin's conclusion that egalitarian insurance will leave some involuntary disadvantage in place. Without these considerations, Dworkin says, his claim that "hypothetical wage insurers would not insure at high levels of coverage" - the claim responsible for the fact that insurance will not eliminate such involuntary disadvantage "would be left unsupported." $I d$.

My approach, by contrast, presents a much more general account of the involuntary disadvantage that egalitarian insurance leaves in place but also paves the way for a more deeply principled justification of such disadvantage. The uncompensated involuntary disadvantages that the arguments concerning talent slavery and taste indoctrination pick out arise not as a result of contingent facts about the costs of remedying one or another form of disadvantage but rather as a result of the internal structure of the insurance scheme and of the relations among the participants that the scheme engenders. Moreover, these relations themselves describe a principled ideal of 
This addıcional redistribution should trouble egalitarians. The insurance model was developed, after all, to articulate the egalitarian ideal of equal agency. According to this ideal, people are equal as agents (their nonsubordination as agents is secured) when they have equal capacities to make their lives fulfill their ambitions, including equal capacities to protect against misfortunes that make this difficult. To respect this ideal, egalitarian insurance must offer people identical policies at identical rates (any other insurance scheme subordinates those who are offered less attractive policies or face higher rates). But the redistribution necessary for eliminating involuntary disadvantage violates this principle. To the extent that it requires greater redistribution than the redistribution recommended by egalitarian insurance, eliminating involuntary disadvantage in effect charges talented people and people who have cheap tastes with more insurance coverage than they would have bought and provides untalented people and people who have expensive tastes with more coverage than they could have afforded. Viewed another way, this time from the perspective of the insurance market, the additional redistribution required to eliminate involuntary disadvantage corresponds to insurance coverage people who turn out to be untalented or to have expensive tastes could have afforded only if they had faced cheaper insurance rates than people who turn out to be talented or to have cheap tastes. But this is to subordinate the latter to the former as agents.

Furthermore, the reasons for which people who are offered egalitarian insurance will insure only up to levels that leave involuntary disadvantage

nonsubordination, which arises out of the distinction between approaching persons as patients and as agents. These features of my view will enable me, in the argument to come, to understand the involuntary disadvantage that the insurance model sanctions not merely as a pragmatic (and perhaps unfortunate) necessity but rather as an expression of the egalitarian ideal.

The differences between Dworkin's and my accounts of the involuntary disadvantage that egalitarian insurance leaves in place reflect deeper methodological differences. Dworkin has recently distinguished between two uses of counterfactual constructions such as the egalitarian insurance scheme in philosophical argument: first, to elaborate a principle of justice by reference to a thought experiment constructed from the building blocks that underlie this principie; and, second, to propose an alternative real world that is fairer than our actual world. See id. at 109. Dworkin cites Rawls's appeal to the original position as an example of the first use of counterfactuals and contrasts this with his own appeal to imaginary insurance. He identifies, as an important difference between the two approaches, that counterfactuals employed in the first way may be highly idealized whereas counterfactuals employed in his own, second way must attend to the practical difficulties involved in their actual implementation. Id. at 109-10. Dworkin's turn to the practical in connection with justified remainders of involuntary disadvantage is therefore more than mere ad hocery; it is instead required by his methodological approach to egalitarian insurance. My own turn to the distinction between equal-patient and equal-agent egalitarianism in response to the same problem is, similarly, determined by my own methodological commitments - specifically to using hypothetical insurance in the first (Rawls-like) manner in order to elaborate a theoretical account of nonsubordination. This is not the place for systematic reflection on the relative merits of the two methodologies, but I hope that the arguments to come will reveal at least one advantage of the approach I adopt, by forging a theoretical connection between the insurance model's treatment of involuntary disadvantage and the foundational ideal of nonsubordination that has eluded Dworkin's argument. 
in place-the fear of talent slavery and taste indoctrination-may be naturally recast in terms of more general intuitions, whose expression does not depend on the technical intricacies of the egalitarian insurance scheme. In each case, the fear at the heart of the decision not to insure more heavily - the decision that leaves involuntary disadvantage in place-is that the additional redistribution needed to eliminate involuntary disadvantage would encroach on the integrity of those who had to pay for it. The additional redistribution would require the advantaged to place not only their good fortunes but also their very selves-their life plans, their personal development-at the disposal of the community. And this is a step people are unwilling to take, not even in the name of correcting for morally arbitrary disadvantage.

Accordingly, the redistribution required to secure the nonsubordination of people as patients (by eliminating involuntary disadvantage) requires subordinating some people to others as agents (by discriminating against them in the insurance market). Eliminating luck's differential effects on the distribution of advantage requires abandoning the ideal of respecting the differential effects of choice. Responsibility-tracking egalitarianism's dual ambition cannot be achieved.

\section{EQUALITY AS AGENTS OR AS PATIENTS?}

Responsibility-tracking egalitarianism seeks to secure the nonsubordination of people as agents (as free choosers) and as patients (as recipients of luck) at the same time. This is a high ambition. The two cases of nonsubordination demand opposite responses to differences in people's fortunes. If people are to be treated equally as agents, their choices must separate them - they must be allowed to be agents separately. If people are to be treated equally as patients, their luck may not separate them-they must be made patients together. Responsibility-tracking egalitarianism's high ambition cannot be achieved because people who are treated equally as agents will not bind themselves together absolutely as patients (they will not buy enough insurance to eliminate involuntary disadvantage). Allowing people to be agents separately-allowing their choices to separate themtherefore involves accepting that they must, to some extent, be patients separately also. My main aim in this Essay has been to diagnose this dilemma, to reveal that egalitarians must choose between securing the nonsubordination of people as agents and securing their nonsubordination as patients. But this choice, once revealed, is too tempting a subject for me to ignore. Accordingly, I conclude my argument by offering two tentative suggestions about how I think egalitarians should choose.

Both suggestions support the conclusion that egalitarians should aim to secure the nonsubordination of people as agents and that the involuntary 
disadvantage that the insurance model leaves in place is consistent with egalitarian nonsubordination properly understood. ${ }^{77}$ But neither suggestion constitutes an argument in favor of this conclusion or even an outline of how such an argument might go. Instead, I shall aim only to make some preliminary remarks about how the distinctions I have developed allow an egalitarian of this stripe-an equal-agent egalitarian-to resist two familiar and intuitively powerful objections that might be brought to bear against her position and that have, moreover, plagued egalitarian political thought quite generally. On the one hand, the fact that securing the nonsubordination of people as agents requires allowing them to be agents separately (and the contrast between this ideal of nonsubordination and the notion that the nonsubordination of people as patients requires them to be patients together) allows the equal-agent egalitarian to resist certain libertarian ideas, pressed from without egalitarianism, which assert that egalitarian redistribution fails to appreciate the individuality of persons. And, on the other hand, the fact that securing the nonsubordination of people as agents depends on a cooperative insurance scheme established among identically situated people allows the equal-agent egalitarian to resist certain collectivist ideas, pressed from within egalitarianism, which assert that distributive principles that fail to eliminate involuntary disadvantage violate the egalitarian ideal of community. The equal-agent egalitarian answers both objections in the same way, by explaining that the pattern of redistribution equal-agent egalitarianism recommends (including

77. As I noted earlier, see supra note 76 , Dworkin's very different account of the involuntary disadvantage that egalitarian insurance leaves uncorrected has come under criticism. For example, Michael Otsuka and Robert van der Veen have characterized Dworkin's approach to egalitarian insurance as emphasizing equality in an imaginary state before luck has operated (equality that Otsuka calls "ex ante" and van der Veen calls "procedural") to the exclusion of equality in the actual luck-ridden world (equality that Otsuka calls "ex post" and van der Veen calls "substantive"). See Otsuka, supra note 76, at 49-50; van der Veen, supra note 48, at 59-60. These criticisms may be understood as taking Dworkin to task for departing from his own theory's core, responsibility-tracking commitment that "if someone has been born blind or without talents others have, that is his bad luck, and, so far as this can be managed, a just society would compensate him for this bad luck." DwORKN, supra note 5, at 287. Otsuka's and van der Veen's criticisms express the concern that although Dworkin says that egalitarian insurance "aims to put people in an equal position with respect to risk, rather than to negate risk altogether," and that this shows "equal concern" for all persons, id. at 341, the pragmatic arguments that Dworkin marshals in support of leaving involuntary disadvantage uncorrected cannot authorize the retreat from the basic egalitarian ideal that this conclusion involves.

The differences between my presentation of egalitarian insurance and Dworkin's enable me to answer this criticism. In place of Dworkin's piecemeal account of the involuntary disadvantage that egalitarian insurance leaves in place, I have developed a systematic argument that connects this uncompensated disadvantage to the internal structure of the insurance scheme. And in place of Dworkin's pragmatic justification of such uncompensated disadvantage, I shall now develop a principled argument connecting the insurance model and the disadvantage that it leaves in place to an account of nonsubordination that, I believe, comprises the foundation of the egalitarian ideal. Insofar as I succeed in these aims, I will show that the involuntary disadvantage that the insurance model leaves in place is not a retreat from but rather an expression of egalitarianism. 
both the disadvantages it eliminates and those it leaves in place) describes a form of life in which independent persons may share on equal terms.

I begin by considering the first objection, which starts from the idea that to the extent egalitarians propose to bind people's fortunes together, they treat human capital-most significantly talents, but also, I might add, cheap tastes, good health, and other special traits-as what Rawls has called a common or collective asset. ${ }^{78}$ Libertarian critics of egalitarianism attack this move, claiming that it amounts to giving people property rights in others and therefore involves treating those with more human capital not as distinct individuals who are independent sources of authoritative moral claims but merely as means used in serving the ends of those with less. ${ }^{79}$ Powerful intuitions suggest that this violates the rights of those with more human capital, hence the common (if somewhat hyperbolic) claim that redistributive taxation-taxation that takes from those who earn more and gives to those who earn less - enslaves the talented.

An egalitarian who does not want to reject the intuition that people may not be used merely as means-and I certainly do not want to reject this intuition-must find a way to characterize egalitarian redistribution so that it respects individuality and does not create property rights in other people. The most direct way to do this is to claim that egalitarianism gives people rights in one another's human capital but not in their persons. But this claim bears a significant persuasive burden. As Robert Nozick says, it involves pressing "very hard" on the distinction between people's human capital and their persons. ${ }^{80}$ Why should someone accept, for example, that when his talent is used to serve others only it, and not he himself, is being used as means?

The insurance model of equal agency answers these questions and explains why the egalitarian redistribution it recommends collectivizes only people's capital and not their persons. People in the hypothetical insurance markets insure not against having particular abilities or tastes but rather against the wages and prices they will face. The insurance market therefore separates people's persons from the value of their persons as capital. The redistribution the insurance model of equal agency recommends does use the capital value of people's capacities-the value attributed to these

78. RAWLS, supra note 1 , at $102,179$.

79. See, e.g., ROBERT NOZICK, ANARCHY, STATE \& UTOPIA 172, $228-29$ (1974). Anderson reports a similar response from the right, saying that the egalitarian effort to eliminate involuntary disadvantage, which she calls "luck egalitarianism," opens itself up to the claim that "egalitarians are oblivious to the proper timits of state power and permit coercion of others for merely private ends." Anderson, supra note 2, at 289, 287 (emphasis added). These objections recall Kant's idea that one should treat humanity "never simply as a means, but always at the same time as an end." IMMANUEL KANT, GROUNDWORK OF THE METAPHYSIC OF MORALS 96 (H.J. Paton trans., Harper Torchbooks 1964) (1785).

80. NozICK, supra note 79 , at 228 . 
capacities by the market-as a means to serve others. But at the same time, equal-agent egalitarianism restricts the redistribution it allows according to limits set by an insurance scheme in which people insist on precisely the distinction between their capital values and their persons and refuse to insure at levels that, by leading to talent slavery or taste indoctrination, put their persons at risk. In this way, equal-agent egalitarianism begins to answer the libertarian attack on redistribution. Indeed, the substance equalagent egalitarianism imparts to the distinction between people's capital values and their persons, the distinction's practical bite, appears right on the face of the theory. Its measure is the involuntary disadvantage equal-agent egalitarianism leaves in place. Equal-patient egalitarianism, by contrast, does not recognize the danger eliminating involuntary disadvantage poses to the independence of people's persons, and for this reason finds the libertarian attack more troubling.

Second, I wish to consider an objection Cohen has raised against what he calls the Pareto argument for inequality - more precisely for leaving some involuntary disadvantage in place-which he identifies as one of the arguments behind Rawls's difference principle. ${ }^{81}$ Cohen believes that the Pareto argument for inequality should be rejected by egalitarians because it is inconsistent with the egalitarian ideal of community, and I shall begin by explaining, as briefly as possible, the argument Cohen develops to support this conclusion. ${ }^{82}$ My main effort, however, will not be directed at exploring and assessing Cohen's argument but rather at distinguishing how equal-agent egalitarianism and the Pareto argument stand with respect to this argument. Although, like the Pareto argument, equal-agent egalitarianism recommends leaving some involuntary disadvantage in place, it does not contravene the egalitarian ideal of community. I introduce Cohen's reflections on the Pareto argument in order to develop this contrast and thereby take an important first step toward overcoming the preconception (which Cohen's arguments do not entail but nevertheless encourage) that the egalitarian ideal of community requires eliminating involuntary disadvantage.

81. The difference principle states that social and economic inequalities are to be arranged so that they are "to the greatest benefit of the least advantaged." See RAWLS, supra note 1, at 83, 302. It therefore countenances involuntary disadvantage when such disadvantage benefits the worst-off.

82. Cohen has developed this objection in a decade-long series of articles. See, e.g., G.A. Cohen, Incentives, Inequality and Community, in EQUAL FrEEDOM: SELECTED TANNER LECTURES ON HUMAN VALUES, stupra note 7, at 331 [hereinafter Cohen, Incentives]; Cohen, supra note 17; G.A. Cohen, Where the Action Is: On the Site of Distributive Justice, 26 PHIL. \& PUB. AFF. 3 (1997) [hereinafter Cohen, Where the Action Is]. As Cohen himself points out, although the Pareto argument finds a place in Rawls's work, it "is not Rawls's official argument for difference-principle inequality, because this argument dispenses with the device of the original position." Cohen, supra note 17 , at 161 . 
The Pareto argument tempers the egalitarian premise that involuntary differences in advantage are morally illegitimate with the idea that involuntary disadvantage is justified when it makes the worst-off better off. ${ }^{83}$ Next, the argument adds the factual claim that because the talented will work more productively when they can keep more of their product for themselves - that is, when there is less redistribution - the worst-off will be better off when some involuntary disadvantage survives than when all involuntary disadvantage is eliminated. ${ }^{84}$ The extra redistribution needed to eliminate involuntary disadvantage will, as it were, reduce the total advantage there is to go around, so that while the worst-off will no longer be disadvantaged compared to the better-off, this will be achieved only at the cost of making them, absolutely, less advantaged. For this reason, so the argument goes, egalitarians should not seek to eliminate involuntary disadvantage. ${ }^{85}$

Cohen responds to this argument by asking why the talented produce less at the high levels of redistribution associated with eliminating involuntary disadvantage - why the productivity of the talented depends on how much of their product they are allowed to keep. He answers that by far the greater part of the reason for which the talented produce less at higher levels of redistribution is not that productive jobs carry a high labor burden or that the talented are unable to work productively without the incentive of being allowed to keep the lion's share of their product, but rather that they are simply unwilling to do so. ${ }^{86}$ The Pareto argument, Cohen concludes, treats this unwillingness as a justification for failing to eliminate involuntary disadvantage.

This is the element of the Pareto argument at which Cohen takes aim, the element that he says is inconsistent with the egalitarian ideal of community. The Pareto argument supports retaining involuntary disadvantage because the talented are unwilling to work productively when there is enough redistribution to eliminate involuntary disadvantage. But this allows the talented to secure advantages "by virtue of the bargaining power associated with their superior talent," even though "that superior

83. This formulation raises the familiar question of whether egalitarianism should be concerned only or primarily with the worst-off (the most disadvantaged) or also with the worseoff (the simply disadvantaged) more generally. Nothing in my argument turns on this question, and so I shall leave it to one side.

84. Both parts of this factual claim may, of course, turn out to be false. The productivity of the talented may turn out to be inelastic with respect to the level of redistribution, and, even if lower levels of redistribution do encourage the talented to be more productive, the benefits of this additional productivity may never reach the worst-off. The power of Cohen's argument is that it avoids these familiar and intractable empirical controversies altogether because it applies even conceding the anti-redistributive positions on such matters.

85. This presentation of the Pareto argument is taken, roughly, from Cohen, Incentives, supra note 82, at 339. Similar presentations of the argument may also be found in Cohen, supra note 17, at 160-61, and Cohen, Where the Action Is, supra note 82, at 6 .

86. See Cohen, Incentives, supra note 82 , at 359 n. 18 . 
talent was originally [under the egalitarian premise] ... said to justify no special reward," being itself involuntary and therefore arbitrary from the moral point of view. ${ }^{87}$ This is a naked exertion of power by the talented, and being naked, it is one they cannot justify to the untalented, at least not on egalitarian terms. As Cohen says, the Pareto argument places the talented "out of community" with the untalented: Instead of answering the untalented's legitimate claims, the talented manipulate the untalented ${ }^{88}$ This is something egalitarianism cannot allow. It violates the fundamental egalitarian ideal of tying all people's fortunes together without subordinating any of them.

Cohen's own development of the egalitarian objections to the Pareto argument is, of course, much more involved than the brief sketch here recognizes. But my purpose in discussing these ideas is not to evaluate them on their own terms but rather to introduce a contrast between the Pareto argument for allowing involuntary disadvantage to survive and the argument proposed by equal-agent egalitarianism. And indeed, the contrast between these two arguments could not be much clearer. Where the Pareto argument's justification for involuntary disadvantage involves caving in before a threat issued unilaterally by the talented, the equal-agent egalitarian justifies retaining some involuntary disadvantage from a perspective in which the talented and the untalented can share. Because the level of egalitarian redistribution is determined by the insurance decisions of people who do not know how their luck will turn out, the lucky and the unlucky - the talented and the untalented - are equally represented in the process that determines how much redistribution equal-agent egalitarianism requires and how much involuntary disadvantage it leaves in place. This argument for leaving involuntary disadvantage in place therefore turns not on a threat made by the talented once they know they are talented (as does Rawls's Pareto argument) but rather on a consideration (talent slavery) that is equally accessible to all from the ex ante point of view-a point of view adopted before people know their own talents and that the talented and untalented can therefore share. Indeed, the equal-agent egalitarian argument

87. Cohen, supra note 17 , at 174 . The quotation comes from remarks directed specifically at Rawls's difference principle. Indeed, one of Cohen's themes is to demonstrate that Rawls's ideas contain both the version of the Pareto argument Cohen attacks and the egalitarian ideals of community that underwrite the attack. See, e.g., Cohen, Incentives, supra note 82, at 378-97; Cohen, supra note 17 , at $166-68,173-75$.

88. Cohen, Incentives, supra note 82 , at 354 . Here I am only hinting at Cohen's vision of community as involving certain ideals of interpersonal justification among the community's members. For Cohen's development of this account, see id. at 347-55. One feature of Cohen's account that is apparent even from the brief presentation I have provided is that its emphasis on interpersonal justification leaves no fundamental place for institutions in the construction of community. For an attack on Cohen's arguments that aims to resuscitate the difference principle and the Pareto argument on the basis of the fundamental role institutions (and, relatedly, publicity) play in egalitarian idcals of community, see Andrew Williams, Incentives, Ineguality, and Publicity, 27 PHIL. \& PUB. AFF. 225 (1998). 
applies even when insurance is structured so that premiums depend on maximum possible wages rather than on actual wages, even, that is, when the talented will be rendered unable strategically to threaten to withhold their talents, unable to adopt a perspective apart from the untalented.

For this reason, the involuntary disadvantage that survives the redistribution recommended by equal-agent egalitarianism does not contradict the egalitarian ideal of community but, to the contrary, is an expression of this ideal. According to the equal-agent egalitarian's view of community, each member shares in the good and bad fortune of every other member, but only to the extent determined by the equal choices of all. The egalitarian community, on this ideal, is a community of agents rather than patients. ${ }^{89}$ This remains, admittedly, a rough and ready ideal, in need of further elaboration at another time. But it is enough, I think, to counterbalance the misleading preconception that establishing an egalitarian community requires eliminating involuntary disadvantage. Instead, eliminating involuntary disadvantage now appears, in a new light, to involve violating the egalitarian ideal of community by subordinating certain people to others as agents. With this thought in place, I can return to complete, however tentatively, the intuitive characterization of egalitarianism with which I began. Egalitarianism ties people's fortunes together, but no more intimately than, approaching the question from an equal starting point, people would choose them to be tied.

89. This movement of thought suggests an answer to Anderson's most basic criticism of the egalitarian tradition I have been considering. Anderson argues that whereas egalitarianism "must supply principles for collective willing-that is, for what citizens should will together, not just for what each can will individually," the insurance model focuses on "market choices" that "offer no guidance whatsoever to what citizens are obligated to provide one another on a collective basis." Anderson, supra note 2, at 309-10 (emphasis omitted). The model of egalitarian community described in the main text suggests that Anderson fundamentally misunderstands the purpose of the hypothetical insurance scheme, at least as I have cast it. The aim of the insurance scheme is not to get each real person to identify privately with one of the insurance purchasers it describes but rather to get all real people collectively to identify with the vision of equality it develops and collectively to will the redistribution it recommends. 


$$
\text { ネネネ }
$$

Imaged with the Permission of Yale Law Journal 


\title{
Copyright Term Extension and Intellectual Property as Constitutional Property
}

\author{
Paul M. Schwartz ${ }^{\dagger}$ and William Michael Treanor ${ }^{\dagger \dagger}$
}

\section{INTRODUCTION}

Since the ratification of the Constitution, intellectual property law in the United States has always been, in part, constitutional law. Among the enumerated powers that Article I of the Constitution vests in Congress is the power to create certain intellectual property rights.' Yet, until very recently, this Clause and its meaning-and the larger subject of the relationship between constitutional law and intellectual property-received little attention from constitutional law scholars. ${ }^{2}$ In a short period of time,

$\dagger$ Professor, Brooklyn Law School. Berlin Prize Fellow, American Academy in Berlin, Germany (Fall 2002); Transatlantic Fellow, German Marshall Fund, Transatlantic Program, Brussels, Belgium (Spring 2003). Professor Schwartz would like to thank Gary Smith of the American Academy in Berlin as well as Bill Antholis and Bill Drozdiak of the German Marshall Fund for offering stimulating and collegial international environments for scholarship. Finally, Dean Joan Wexler of Brooklyn Law School provided support to Professor Schwartz through the Dean's Research Fund as well as through her encouragement during every stage of this project.

+† Dean, Fordham Law School. From 1998 until 2001, Dean Treanor served as Deputy Assistant Attorney General, Office of Legal Counsel, United States Department of Justice. The views expressed in this Essay do not necessarily represent the views of the Department at that time or at the present.

Earlier versions of this work were presented at the Fordham International Intellectual Property Conference in April 2002 and in Dean Treanor's Fall 2002 Constitutional History class at Fordham. The authors would like to thank the participants and audience at the conference and the class members. We would also like to thank David Barron, Tricia Bellia, Michael Bimhack, Jill Fisch, Martin Flaherty, Jane Ginsburg, Abner Greene, Hugh Hansen, Vicki Jackson, Ted Janger, Sonia Katyal, Marty Lederman, Lance Liebman, Mark Patterson, Peggy Radin, Jocl Reidenberg, Dan Richman, David Saul Schwartz, and Howard Shapiro for their suggestions and comments on this Essay.

1. U.S. CONST. art. I, $\$ 8, \mathrm{cl} .8$ (authorizing Congress to "promote the Progress of Science and useful Arts, by securing for limited Times to Authors and Inventors the exclusive Right to their respective Writings and Discoverics").

2. Thus, the second edition of Laurence Tribe's treatise on constitutional law did not find the Copyright Clause to be one of the three areas of domestic power granted to Congress-commerce, taxing, and spending-that had "provoked sufficient legislation and litigation to generate 